犬の舌粘膜分裂線の加令的変化について

九州歯科大学解剖学教室 (指導 : 中山種秋教授)

中道正義

（昭和44年 4 月15日受理）

（本論文の要旨は第10回基礎歯科医学会総会に扔いて発表した）

\title{
A STUDY ON AGE CHANGES OF THE SPLITTING LINES IN THE LINGUAL MUCOUS MEMBRANE OF THE DCG
}

\author{
By \\ Masayoshi NAKAMICHI \\ Department of Anatomy (Director : Prof. Taneaki NAKAYAMA) \\ Kyushu Dental College, Kitakyushu, Japan
}

In the past, many investigators have worked on the field of splitting lines, however their attention has been almost neglected on the subject of the irregular splitting lines. In 1957 a report by professor T. NAKAYAMA, M. D. was published which stated that the irregular splitting lines might be a direct functional manifestation which occurs as a defense reaction of the tissue. Hence, study was conducted on age changes and their relation to the splitting lines in the mucous membrane of the tongue. The muscular organs, tongues were obtained from $72 \mathrm{dogs}$ of red and short hair type, from 60 days pre-natal growth to 14 years of age.

The following summary contains the conclusions of the study :

1. It is possible to differentiate the splitting lines-system and the irregular splitting lines in the mucous membrane of the tongue.

2. The direction of the splitting line indicates the direction of its development. For the irregular splitting lines, it was assumed that there are two types: one is a result of friction of developing power and the other accompanies general tongue function.

3. The age changes of the splitting lines demonstrates aging process of tongue development. The differrential stages are :

a. Pre-incipient growth stage (60 days pre-natal)

b. Incipient growth stage (10-30 days post-natal)

c. Rapid growth stage of transverse and thick development (2-6 months post-natal)

d. Rapid growth stage of longitudinal development (7-11 months post-natal)

e. Maturation stage (1-6 years post-natal)

f. Atrophy stage (10-14 years post-natal)

4. It is a general occurance to have many resulting irregular splitting lines within 
the continuous lines system itself on the lingual mucous membrane. And this result is, the author thinks, based on the fact that the tongue is a very active muscle organ and is subject to polymorphic exercise.

\section{目次}

I 緒言

II 実験材料ならびに方法

III 所見
A 舌背
B 舌下面

IV 総括ならびに考按
A 舌背
B 舌下面

$\mathrm{V}$ 結論

VI 文献

\section{I 緒言}

分裂線は, あらゆる器官, 組織の構築を知る簡便な方 法として，古来幾多の学者により利用されて来た．軟組 緎に関しては, Dupuytren (1836)を始めとして Langer (1861), Hoffman (1881), Burkard (1913), また, 長谷部 $(1917)^{4)}$, 梶村 (1926) および福井 (1932〜36) 5) らの邦人により, 軟組織における線維構築の研究が,

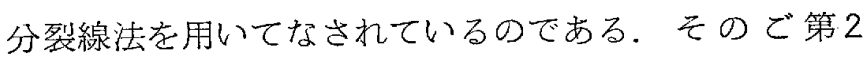
次大戦時における研究の空白を見るが，戦後ふたたび， 該分裂線法による研究も漸次散見されるにいたり，本 邦に拉いては，軟 組織に 関するものとして，小木層 (1942), 友田 (1949), 山本 (1950), 連理（1951 52)，西尾（1951）および橋本 (1954)7）らの報告を見る のである．しかしながらてれらの業績は，各組織の線維 構築の状況を，たんに分裂線法によって明らかにしたの みであり，しかも線系のみを観察し，不整裂線の存在之 その意義をいまだ認めていない. 1956年，中山3)は，日 本解剖学会九州地方会 (熊本) 飞扔いて，あらゆる場 合における不整裂線の出現とその意義を述へ，引き続き 1957年，骨分裂線に関する教室業績を総合し”骨分裂線 特に不整裂線の意義, として九州歯科学会誌上に発表 し，不整裂線は発育方向の乱机であり，あるいは内的発 育力の衝突，あるいは機能その他による外力的な影響に 伴う発育方向の乱れである。つまり不整裂線は骨組織自 身の示す一つの防禦反応としての直接的な機能表現であ ると主張していらい，同門の教室員は軟組織に関してあ この見解が成り立つか否かを検討して来たのであって, 大森 $(1957)^{9)}$ は卵殼膜について，阿部 (1959)10》は犬眼 球強膜について，扣なじく阿部は同年人胎児皮膚につい
て, 鶴丸（1959）12）は犬精巣鞘膜について，おなじく鶴 丸は1960年犬の卵巣露について，松隈（1960)14）は犬の 脾被膜について, 沖重 (1960)15) は大胃嶈膜について, それぞれ，それら被膜の分裂線について加令的変化を 観察している．その結果，骨の場合に拈汀ると全く同様 に被膜分裂線が線系上不整裂線とよりなるものであり， この両者を総合観察することによって, 分裂線の加令的 変化が器官発育に伴う該被膜の発育過程図であるという 見解に到達する事を述へている，特に大森の卵殻膜にお ける不整裂線の出現, 阿部の眼球強膜に扔ける不整裂線 の出現, 抢よび鶴丸の卵巣震上に抢ける不整裂線の出現 は, それら器官の機能抒よび内部発育が, 外力的影響と して不整裂線を出現せしめたものであり, 強く與味を覚 えるところである。

野見山（1968）16）は，数種哺乳動物の舌粘膜固有層に 怙ける分裂線を明らかならしぬているが, 加令的変化は その検討の必要性を述べただけに留まっている，すなわ ち私は犬の舌を用いその粘膜分裂線の加令的変化を検討 し，その意義を詳細ならしぬんとして本実験を試みた次 第である。

\section{III実験材料ならびに方法}

実跧材料は赤短毛の雑犬で，胎你60日（2），生後10 日 (3), 生後20日（3), 生後30日 (4), 生後2 力月 (4), 生後 3 力月 (4), 生後 4 力月 ( 3 ), 生後 5 力 月 ( 3 ), 生後 6 力月 ( 3 ), 生後 7 力月 ( 3 ), 生後 8 力月 (3), 生後10力月 (3), 生後11力月 (3), 生 後 1 年 (6), 生後 2 年 (3), 生後 3 年 ( 3 ), 生後 4 年 (3), 生後 5 年 (3), 生後 6 年 (2), 生後10年 (2), 生後14年 (1), の計64例である. 材料の年令決 定は人手時に明膫なすの以外は，Miller，小西および加 藤らの犬の歯牙萠出時期, そのた菌牙の磨籷, 脱落など 亿関する時期的諸事実を厳密に検討してその年令を決定 したが，な抢かつ決定困難の場合はこれを除外した．実 験に際しては, クロロホルム麻酔後舌を摘出し, 摘出さ れた舌は直ちに熱湯を含ませた脱脂綿により，繰り返し 表面を払拭して上皮を完全に剥離除去せしめた後, 通法 のごとく穿刺し固定液（70\%アルコール）中に保存され た．ただし穿刺は各面に直角に行ない，余分の墨汁を水 洗しながら続行された，観察に当っては，まず写真撮影 を行なった後，該写真の陽画之実物とを照合しながら， 
不分明な裂線を明らかならしめるためにRotring 0.1mm 巾を用いて裂線を明黒ならしめた。乙れによってその加 令的变化状況を観察したものである.

ちなみに, 凟料のうち年令決定上の不安, 写真撮影の 不適, 固定時の強い変形などにより計 9 例は観察対象よ り除外されてある。

\section{III 所見}

\section{A 舌背}

\section{1 胎仔60日 ( I図, (1) )}

No.1 およびNo.2 いつれ手全が不整裂線に充たさ れる。

\section{2 生後10日（I図，（1），（2））}

No.8, No.9，No.10の3 例いづれ屯舌根部両側に後 方に凸なる弧状線系化の傾向を，舌体の両側縁部に緹走 線系化の傾向をそれぞれ示しているととが目立ってい b.

\section{3 生後20日 (I図, (2) )}

No.11，No.13の2 例は舌根部では後方に凸なる弧状 線系群，舌体部には斜走線系群の明らかな出現を認める が，個々の線茲の間には多少の乱れた裂線を挟んでい る. しか屯全般的に眺める時舌根部中央，舌体の側縁部 ならびに舌尖部は不整裂線団に充たされるが，舌尖部の 不整裂線団は放射状線系化の傾向を示している。な括 体正中部は 1 ～2 連の不整裂線系をなしている。

No.12例あほとんど全く同様であるが，乙の例はいず れかといえば線系化の傾向が上述の 2 例に比して弱いこ とが目立つだけである。

\section{4 生後30日 (I図, (3) )}

No.14, No.16, No.18, No.20 の4例は, 全例共に 生後20日の場合亡差異を認如難い.

\section{5 生後 2 力月 (I図, (4))}

No.24, No.25, No.26, No.27 の 4 例全部を概観し て，舌根部に执いては今まで後方に山なる弧状線系群で あったものの一部が中心部より後外側に向って走る弧状 線系化の傾向を示すため，乙れらと前外側に向う弧状線 系群とによって二分される傾向が窥われ，しかもこのこ とが舌根部全体としては不整裂線団の著明化を来たして いる．したがって特に中心部より後方ならびに側方にか けて限局される不整裂線団が目立って来ている．舌体の 正中部に扣ける細長い不整裂線団, 舌尖舌体の境界亡す いうべき正中部の不整裂線団，ならびに舌体舌尖移行部 の外側縁部における不整裂線団の限局化が著明である。 ただし外側縁部の不整裂線団は必ずしあ左右対称的であ り，また同程度であるという訳ではない，舌尖部も前 1
カ月の時期よりむむしろ不整化した傾向が強く，舌体両 側の斜走線系の状況には，生後20日，生後30日のもの之 大差はないが，個々の線系の乱れはむしろ激化している ように見える。

\section{6 生後 3 力月 (I図, (5))}

No. 30, No.31の2 例は, 生後 2 力月乙比較して全面 に扔ける線采の不整化が目立っている，ただし舌尖部は 線系化の傾向がむしろ強い. No. 32例はこれら2 例と大 差祊いが，正中部に一連の縦走線系を明らかに認めるこ とが著しく異なる点である.No.33例は上述の3 例とは 全く趣を異にする。特に舌体の中 高部に横 走線系化の 強い傾向を認めるととである。之の他舌根部に拈りる後 方に凸なる弧状線系群, 舌体外側縁部の縦走線系群, 舌 尖部左側半の $1 \sim 2$ 弧状線系等明瞭な線系とそれらの 間を充たして, 舌根中央部, 舌体正中部, 舌根舌体移行 部の両側，舌尖端部等の不整裂線団が著明に限局される 点である。

\section{7 生後 4 力月 (I図, (6) )}

No.35, No.36, No.37 の3 例はほとんど全く同様で あり全体的に線系が明瞭化するが一方不整裂線団毛限局 性が強くなるように思加机る。前 3 力比しての期の 特徽と見られる点は，舌体後半部の領域が左右相連なる 傾向を示しながら斜走性ではなく弧状線系化の様相を示 す点である.このような状況のために生後 2 力月に执 て記述した正中部の細長い不整裂線団は舌体後半部で中 断された形となり, 弧状線系化の裂線群と斜走線系群と の隣接域に限局される不整裂線団を認め，また舌根部と 舌体部との閒においては弧状線系化の不完全のために舌 根部不整裂線団が舌体後半の領域まで拡散された状況を 呈している。 な括舌体と舌尖移行部の正中に屯限局され た不整裂線団の出現を認め，汃つ各線系群の所々に不整 裂線団の小領域が見られる.

\section{8 生後 5 力月 (I図, (6), (7) )}

No.38, No.39, No.40 の 3 例は生後 4 力月とほとん ど全く同様であるが, 全例について生後 4 力月よりあ更 に整然とした状況である。しかしながら不整裂線団は所 々に見られるのであって，全部が線系化したという意味 ではない.

9 生後6力月 (I図, (7), (.8))

No.41，No.42，No.43 の3例いづれ方生後 4 力月お よび生後 5 力月とはとんど全く同栐であるが，全般的に 不整裂線団の限局性が弱まった感じが強い。

10 生後 7 力月 ( I図, (8))

No44',No.46’の 2 例はほとんど同様の状況圭示して 
いる.すなわち生後 4 力月に拉いて舌体後半部に出現し た弧状線系化の傾向に伴う変化は，生後6力月までほぼ 同様に見られたのであるが，乙の時に至ればその弧状の 傾向は逆に斜走線系化して舌根部に集中的な印象を与え てくる，したがって具体的にいえば斜走線系群が著しく 增加して舌根部の不整裂線団は後方にせばめられている 状況である，ただしNo.45’では上述の2例とは全く趣 を異にして，一口にいって線系が歪を受けて種々の方向 を示したような印象である。

11 生後 8 力月（I図，（9））

No.48' は生後 7 カ月の 2 例 (No.44', No.46') の状 況之相似ている. No.47', No.49'の2 例はほぼNo.48’ 上同様の傾向ではあるが，全般的に乱れの傾向が強く， かつ, 舌根部へ向っての集中度が弱い。

12 生後10力月（I図，（9），(10）

No.51', No. 52', No. 53' いずれも生後7力月の 2 例 (No. 44', No.46’) ならびに生後8 力月の2 例 (No 47’，No49'）とほぼ同様の状態である。すなわち舌体部 は不整裂線を挟む斜走線系に，舌尖部は不整な裂線を挟 む明瞭な放散線系に充たされる。舌根部は不整裂線団に 充たされ，舌体之舌尖の境界に当る正中部にも，また両 側縁部にあ限局された不整裂線団を認める事ができる。 なお，正中部は一連の不整裂線系であり，後方は舌根部 の不整裂線団に，前方は舌尖舌体の境界に当る正中部分 の不整裂線団に移行する。

13 生後11力月（I図，(10)，(11））

No. 54', No. 55', No56'いずれあ生後10力月の状況之 変化を認めない, 生後 7 力月以降生後 8 力月, 生後10 万 月, 生後11カ月いずれも舌体後半部の舌根上直接する部 において，乱れの状況が増強していることが目立ってく る.

\section{4 生後 1 年（I図，(11），(12）}

No.46, No.47, No48, No.49, No.50, No.51 の 6 例は，個々の例に扣いては多少の差異を否定出来ない としても，いずれも整然たる線系化の状況が印象的であ り，舌根部を除き全体が葉脈状線紋の状を呈している. すなわち正中部はただ一連の不整な裂線系を見るのみで あり，その他の不整裂線団は彷来の位置に明瞭な限局を 示している.

15 生後 2 年 ( I 図, (12), (13) )

No. 59 , No. 64, No. 52 の 3 例は生後 1 年と大差を認 めない.

16 生後 3 年 (I困 (13), (14))

No. 66, No. 67, No. 68 の 例, 前年に比し大差を認
めない。

17 生後 4 年（I図, (14) )

No. 69, No71, No.72の 3 例, 前年に比し大差を認め ない.

18 生後 5 年 (I図, (15) )

No. 74, No.75, No.77 の 3 例, 前年に比し大差を認 めない.

19 生後6年（I図，(15)，(16）

No. 78, No.79の 2例, 前年に比し大差を認めない。

20 生後10年 (I図, (16))

No. 80, No.81の2例いずれむ全面的な線系の乱れが印象 的である。すすなわち個々の線系の走行自体が不整になる と共にその各所に乱机の裂線を挟えだ状況が出てくる.

21 生後14年（I図，（16）

No. 82 例は生後10年之同様であり, 線系の乱れは更に 増強された感じである。

\section{B 舌下面}

舌下面の観察に当っては，舌小帯附着部を通る横線を 考えて正面図ではそれより前方を，両侧面図では後方を それぞれ舌下面の舌尖部，右側部ならびに左側部として 観察した。 以後舌下面の云々とは特別に記述しないでた んに舌尖部, 右側部, 左側部として記述する。

なお，記述の必要上，舌底および舌の固有部と言う言 葉を使用するが，このような概念は Millerの Anatomy of the dog の中にあ見える事であって，外舌筋によって 形成される部舌底と呼び，内舌筋によって形成される 部を舌の固有部とする。

1 胎子 60 日 ( I図, (1) )

No. 1, No.2の 2 例を通じて舌尖部, 右側部ならびに 左側部すべて不整裂線に充たされるが，両側部で縦走線 系化の傾向が窅える.

2 生後10日 (I図, (1), (2))

No. 8, No.9, No.1003 例を通じていずれも舌尖部 では，その中央部に後方に凸なる1〜2の瓜状線系を認 める. 両側部に抢いては, 舌固有部では1〜2連の縦走 線系が認められるのみでほとんど不整裂線であり，舌底 部ではオトガイ舌筋切断縁より舌固有部に向け放散的線 系化の傾向を持つ不整裂線団に充たされている.

3 生後20日 (I図, (2))

No.11，No.12，No13の3例を通じいず机す生後10日 と大差を認めない。

4 生後30日（I図，（3）

No.14, No.16, No.18, No.20の 4 例を通じ生後10 日ないし20日と大差を認めない。ただ舌固有部で外側縁 
部に縦走線系の著明な発現が目立っている。

$$
5 \text { 生後 } 2 \text { 力月 ( I 図, (4)) }
$$

No.24, No. 25, No. 26, No270 4 例を通じて舌尖部 は前期に比して中央部の弧状線系の両側が著しく不整裂 線の領域を広めている。すなわち，舌尖部では舌尖中央 部の後方に凸なる弧状線系と, 舌尖両側縁部に执いて末 端が外側縁に向う縦走線系の二つが基本的線系をなし， これら 2 線系の境界域に不整裂線 団が拡大されると共 に, 該弧状線系の前後に, すなわち, 舌尖端寄り之舌小 帯附着部附近とに屯乱れが強く現われている。また前記 弧状線系そのものも乱れの傾向が著しい．

両側部は, 舌固有部では舌尖に向う縦走線系があり, 該線系は舌尖両側縁部の縦走線系乙連なり，内方に凸な る弧状線系群を形成する。舌底部ではオトガイ舌筋切断 縁に沿う $1 \sim 2$ 連の縦走線系が出現する. この舌固有部 之舌底部之の 2 縦走線系の間には，外前方に向う短い斜 走線系の一群が出現する。 また舌底部ではその中央部の 後方域に限局性の不整裂線団が存在する。乙机は丁度舌 固有部の縦走線系と舌底部の縦走線系ならびに斜走線系 に挟まれる領域である。

6 生後 3 力月 ( I図, (5))

No. 30, No31, No.32, No.3304 例を通じ生後 2 力 月の状況がより線系化した状態である．むち万え前記の 不整裂線団はそれぞれ限局性を強めた印象である。

7 生後 4 力月 ( I図, (6))

No. 35,No. 36, No37の 3 例を通じて生後 3 力月上同 様である。

8 生後 5 力月および 6 力月（I図，（6），(7), (8) )

生後 5 力月 (No.37, No.39, No.40), 生後6力月 (No41，No.42，No.43）の6例を通じいずれも全体上 して整然たる印象を失わないが，従来の線系自体が乱れ の傾向を示し，その傾向は５力月よりも更に6力月にお いて著朋である。

9 生後 7 力月 ( I図, (8))

No.44', No.45’, No.46’の3 例を通じいずれも舌尖 部は後方に凸なる弧状線系がその凸彎度を減じてむしろ 短い横走線系化することと, その両側に接して縦走線系 の出現することが特徴的である。したがってまた両側部 の舌固有部加ら舌尖外側縁に流入する内方に凸なる弧状 線系群屯消失して縦走線系化の様相を示している.

10 生後 8 力月, 10力月抢上び11力月（Ｉ図，（9）, (10), (11))

生後 8 力月 (No.47', No.48', No.49'), 生後10力月
(No.51', No.52', No.53'), 生後11力月 (No.54،, No. 55', No.56’) の計 9 例を通じいずれも，前 7 カ月 における傾向がさらに明瞭化した状態である。

11 生後 1 年 $６$ 年 ( I 図, (11), (12), (13), (14), (15) )

生後 1 年 (No.46, No.47, No.48, No.49, No. 50, No. 51), 生後 2 年 (No.59, No.64, No. 52), 生 後 3 年 (No.66, No.67, No.68), 生後 4 年 (No.69, No.71, No.72), 生後 5 年 (No.74, No.75, No.77), 生後 6 年（No.78，No.79），の計20例通じいずれも この時期は，両側部の舌固有部にお打る緹走線系が舌尖 部外側縁に流入して形成する内側に凸なる弧状線系群と して再び出現し，両側の該線系に挟まれる舌尖部は広範 な不整裂線団の領域をなしている。

両側部は, 舌固有部では各期に認められた縦走線系が 存在するが，後力部ではその一部が乱れ従来の舌底部後 方の不整裂線団と合しその領域を広めている。 その他は 従来とほとんど同様である. 要するに該時期 は各線系 群, 不整裂線団の配置が明瞭化した印象と共に舌尖部の 線系が消失して広範な不整裂線団の領域を示すここが最 も特徴的である。

12 生後10年（I図, (16) )

No. 80 , No. 81 の 2 例を通じ舌尖部では，再び線系化 するような感じをあたえ，あたかも生後10力月期を思わ せる状態であるが，すべての線系が全体としてゆるやか な走行を示し，しかも線系そのものの中の乱れが著明で ある。

13 生後14年（I図，(16）

No. 82 例で生後10年とほと九ど同様であるが，線系自 体の乱れが更に著明である。

\section{IV 総括ならびに考按}

以上各年令期の舌背扔よび舌下面に抢ける分裂線の状 況を，その変化を主腿点に記述してきたが，ここで四図

(1)，I図（2）を主体とし，亚図およびI図（1）, （2）を参照して舌の形態形成に関与する固有舌筋，な らびに外舌筋の状況を考慮しながら全年令を通じ総括的 考察を行なうに次の如くである。

\section{A 舌背 (II図, (1) )}

\section{1) 胎仔 60 日}

舌背全面が不整な裂線（1）に充たされるのみであっ て、未代発育方向の定まらない，いわゆる発育前期とで を呼ばれるべき時期であると考える。

2) 生後10日 30日

舌根部では生後10日, 生後20日, 生後30日いずれも僅 
かではあるが弧状線系（2）の出現を認め，舌体より舌 尖にかけては生後10日では外側縁部に僅かな縦走線系（ 3) を認めるのみでそのほかは不整裂線に充たされてい たものが, 生後20日, 生後30日に抢いてはその不整裂線 部が明らかな斜走線系化（4）の傾向を示し，僅かな縦 走線系部は逆汇乱机て側緣部に僅かな不整裂線団（5) を形成している。乙のことは舌根部に横径発育, 雨側縁 部に縦径発育の開始した証左ではあるが，末だ全面的に はその状況を示さず不整裂線のままに留まっていたもの が, 生後20日, 生後30日之至って全面的に, 横径ならび に縦径の発育が開始されたために斜走線系化（4）の著 明な状態を示したもの之思われる。すなわちこの時期は いずれにしてあ，発育初期の段階をよく物語るものであ る上考える。

3 ）生後 2 力月～生後 6 力月

生後 2 力月に打いては, 舌根部に打ける弧状線采群が 一部後外側隅に向う弧状線系化 (6)の出現によって二 分された形となり，そのために該部の不整裂線団（7） は前後両外側へ拡散することが目立ってきている。そし て舌体の正中部には細長い不整裂線団 (8), 舌尖舌体 の正中境界域における限局性の不 整裂線団（9），な らびに舌尖舌体移行部の外側縁部に括ける不整裂線団 （5）が著明となり，舌尖部む不整化（10）の傾向が強 くなっている。

しかも舌体舌尖移行部の外側縁に拈ける不整裂線団 （5）は正確に左右対称的であり同程度であるという訳 ではない.また舌体両側の斜走線系（4）の状況は，生 後20日〜生後30日のもの上大差ないとはいえ，個々の線 系の乱机はむしろ激化しているように見える，生後3力 月のうち 3 例は生後 2 力月よりも線系の不整化が目立っ ているが，逆に舌尖部は線系化の傾向が強い，他の1例 はこれらと全く趣を異にして次に述べる生後 4 力月例之 ほとんど同様である。

生後 4 カ月目の 3 例はいずれも全面的に線系が明瞭化 する一方, 不整裂線団も限局性が強くなっているようで ある.な拉，前 3 カ月に比して特徴と見られる点は舌体 後半部の領域が左右相連なる傾向を示しながら，斜走性 ではなく弧状線系化（11）の様子を示すととである。乙 のような状況のために，生後2力月に打いて記述した正 中部の細長い不整裂線団 (8) は, 舌体後半部で中断さ れた形となり, 後半の弧状線系群 (11) と前半の斜走線 系群 (4) との隣接域に限局された不整裂線団 (12) が 出現している。また舌根部之舌体部之の間においては, 弧状線系化の不完全のために舌根部の不整裂線団が舌体
後半の領域まで拡散された状況(13)を呈するのである。 生後 5 力月例は, いずれも生後 4 力月例之ほとんぞ同様 であるが，すべて生後 4 力月例よりむさらに整然とした 状況を示す．ただし不整裂線団は所々に見られるのであ って, 全部が線系化した意味ではない. 生後 6 力月例は, 生後 4 力月扣よび生後 5 力月とほとんど同様であるが, 全般的に不整裂線団の限局性が弱まった感じが強い，

以上の変化状況は要するに発育初期之考えた生後20日 〜生後30日に比して, 生後 2 力月期の舌根部に打ける後 上隅淌向弧状線系（6）の出現, 又生後 4 力月期の舌 体後半部における弧状線系群 (11) の出現など, 線系の 多様化之不整裂線団の桩大，あるいは新たな山現之消 失，ならびに舌尖部に招ける線系化亡不整化との交替な どである，換言すれば，該期（生後 2 カ月〜 6 力月）は 裂線配列の多様な変化のくり返しを示すものであって, 新たに出現した線系 $(6,11)$ 僙厚径発育の著明化を 示すものであり，同時に不整裂線 団および線系の消長 は, 活発な舌機能の発現と併わせ考えて, いわゆる横厚 径発育著明期之思われる。

\section{$4 ）$ 生後 7 力月～生後11力月}

生後 7 力月に抢いては，前比横厚径発育著明期之考元 た生後 4 力月以降におりる舌体後半部の弧状線系 (11) が，後方舌根中央に向って集中的な感じすら与える急な 斜走線系 (14) と化している点がきわわて注目を引く所 であり，そのためにまた舌体後半部の弧状線系群之舌体 前半部の斜走線系群との隣接域に見られた限局性の不整 裂線団（12）の消失に気付くのである，そのほかはほ之 んじ前期（生後 2 力月〜生後 6 力月）之同様である。 そ してての状況は生後 8 力月, 生後10力月拉よび生後11力 月に至るまでその舌根中央部へ向けて集中的な状況がい くらか減弱する場合が見られるとはいえ，全例に抢いて ほぼ同様に認められるのである，すなわちこの時期は急 な斜走線系 (14) の出現が注目すべき点であって, 縦径 発育の著明化を意味するすのと思われる。いわば縦径発 育著明期と解する次第である.

$5 ）$ 生後 1 年 生後 6 年

生後 1 年より生後 6 年に至る全期を通じ整然たる線系

（15）が著明である．すなわち裂線配列の安定化を意味 するあのであり，生長完了期と考える.

6) 生後10年および生後14年

この時期においては前時期（生後 1 年〜生後 6 年）に おいて整然たる線系を示していたものが再び乱れて，個 々の線系の乱机 (16) のみならず, 線系の走行自体の不 整が注目されるところであり，全面的に不整裂線化した 
印象をすら与えるものである。すなわち生長完了期にお ける裂線配列の安定化が再び崩れた状況であり, 犬の生 活運動の不活発化之併わせ考えて舌機能屯減弱し, 舌自 体が今や萎縮発現の状況を示してきたもの之考えられ， いわゆる萎縮期であると思惟する.

\section{B 舌下面}

1) 胎仔 60 日

胎仔60日では，すべてが不整裂線団（1）に充たされ るといえるが，両側部では縦走線系化（2）の傾向をす でに䇲うことが出来る，とはいえ結局いまだ発育方向の 明確でない時期であり，いわゆる発育前期を物語るもの と考元る。

\section{2 ) 生後10日〜生後30日}

この期に抢いては舌尖部中央に弧状線系化（3）の傾 向を, 両側部の舌固有部汇繸走線系化（2’）の傾向を， そして舌底部にオトガイ舌筋切断縁部より舌固有部へ向 う放散的な線系化 (4)の傾向を示し, 時により各線系の 明確な出現を認㧹る。つまり該期間は横径, 縦径なよ゙ 各種方向への舌発育が明確に開始されたこ之を物語るむ の之考える．すなわち舌発育初期の状況之思惟するもの である.

\section{3) 生後 2 力月～生後 6 力月}

舌尖部中央に打污弧状線系（3）の明確化, 雨側部 の舌固有部に打ける縦走線系が舌尖部外侧縁に流入し て形成される内側に巨なる弧状線系（7）の明確化，お よび舌底部放散線系 (4') の明確化が認められる之同時 に，これら線系が時期の伸展と共にあるいは乱れて不整 化し，あるいは再び線系化を著明ならしぬる，などのく り返しの期間であり, 特に6力月は不整化する傾向が著 明である。もちろんこの間に扔いて各線系間の境界域に は不整裂線団の消長が認められる。すなわち生後 2 力月 は縦径発育を伴いながらも，横径発育優勢を物語る初期 であり，生後 6 力月に拈いてその横厚径発育が弱まり劣 勢に達した時期と思われる．換言すれば生後 2 力月より 生後 6 力月までは横厚径発育著明期之考えられ, 最後の 生後 6 力月の状況は次の時期への転期を物語るものと思 惟される。

\section{4 ）生後 7 力月～生後11力月}

該期は従来の舌尖部に打りる弧状線系（3）方短い横 走線系 (10) と化し，その両側に直接する縦走線系 (11 ）の出現を見ることが特徽的であり，従ってその外側に ある内側に凸なる弧状線系群（7'） む消失して縦走化 し，舌下面全面弜強く縦走線系化（11）の傾向を著明な らしぬている.
すなおちての期は明らかに長径発育優勢を物語るもの で，いわゆる長径発育著明期上考えるあのである。

5 ) 生後 1 年 生後 6 年

この時期は両側部の舌固有部に怙ける縦走線系 (2') が舌尖部外側縁に流入して形成する内側に凸なる弧状線 系群 (12) として再び出現し両側の該線系群に挟まれる 舌尖部は，広筂な不整裂線団(13)の領域をなしている。 両側部は舌固有部では，各期に認められた縦走線系 (2') が存在するが，後方部ではその一部が乱往従来の 舌底部後方の不整裂線団（9）上合しその領域を拡めて いる. 要するに該時期は以上のでとき変化を認めるとは いえ各線系あるいは各不整裂線団の配置が明瞭化した印 象之不整裂線団の領域拡大が特徵的である.

加加る状況は舌背に招ける裂線の安定化上一見矛盾す るがごとき印象を与えるが，実は舌背に拈ける固有層は 本質的にその走行の一定した定形結合組織であるのに反 して，舌下面は本来方向不定な線維よりなる踈性結合組 織であることを考えれば，不整線裂団の領域拡大，各裂 線団の配置の明瞭化は, その形態, 機能の定形化を物語 る屯ので, 舌下面としては舌背と同じく生長固定の時期 を物語るむのと思われる。すすね和生長完了期と思惟す るあのである。

6) 生後10年～生後14年

この期は再び線系化の傾向を感じるが，それはきわめ て不整なむのであり，線系と見るべき流れ自体の中に多 くの不整方向の裂線 (14) を含むむのである. とのとと は舌機能も低下した状況下に, 再び逆方向への力の発現 があって線系化の感じを与えるものであり，いわゆる菱 縮発現の時期を想わせるものである。

\section{$\mathrm{V}$ 結 論}

胎仔 60 日より生後14年にわたる赤短毛の犬について舌 粘膜分裂線の加令的変化を観察し次の如き結論を得た.

1) 舌粘膜分裂線にもやはり明らかに線系上不整裂線 とを区別出来る.

2 ) その線系は舌全体の発育に伴う舌被膜としての粘 膜の発育方向を示現し, 不整裂線は発育力の衝突による むのと舌機能化伴うものとの二群に区別され得る事が推 察された。

3) 以上の観点飞従って舌粘膜分裂線の加令的変化状 況は次の 6 期に区別出来た。

i ) 発育前期（胎仔60日）

ii）発筲初期（生後10日一生後30日）

iii）横厚径発育著明期 (生後 2 力月～生後 6 力月）

iv) 長径発育著明期（生後 7 力月～生後11力月） 
v）生長完了期（生後 1 年〜生後 6 年）

vi）萎縮期（生後10年および生後14年）

4) 舌背之舌下面との状況は，その内部形成の要素た る筋の差異ならびにてれに基づく外形の相異に起因して おのずから別固の状況を示している。しかしながらその 変化状況の意味するものは，両者一体となって良く舌全 体の発育過程を物語るものである。

5 ) 不整裂線のうち舌背舌根部の不整裂線団，および 舌背正中部の細長い不整裂線団は外舌筋の働き特に舌下 制の作用が，舌固有部の発育付刘して強い外力的な影響 をおよ活す結果として現われたいわゆる機能的表現であ ると考える。

6 ）舌体舌尖の境界部外側縁の限局性不整裂線団は下 顎犬雬の機械的刺激に起因する機能的表現ではないかと 推察される。

7) 舌尖部の乱れおよび各時期における線系自体の乱 れの消長は, 固有舌筋の運動に起因する機能的表現之推 察される。

8 ）舌下面に打ける舌尖部の不整裂線は, 固有舌筋の 機能に基づく被膜の防禦反応を意味する機能的表現己考 える.

9 ）生後 6 力月に拈ける舌背正中部の限局性不整裂線 団（No.12），舌下面における舌底部不整裂線団（No. 9）は，内的発育力の衝突による乱机である之考える. もちろんこのほかにあ内的発育力の衝突による不整裂線 の消長は所々に見出される。

10）舌粘膜の分裂線に扔いては恐らく舌が全く筋性の 器官できわめて多様活発な運動を営むために，線系自体 が所々に不整裂線を含む場合がきわわて多く，時によっ て斜裂線系あるいは不整裂線系と呼ぶべきものを見出す ことが特徽的である。

11）特に舌下面の観察に扔いて粘膜を剥離した場合, 粘膜分裂線と筋線維の走行自体とは全く別個であり，た とえ疎性結合組織に氺いてであその被膜に働く張力の方 向に常に線維の配列が左右されることを見たのはきわめ て興味潹く感ぜられた。

稿を終るに当り終始御愁篤なる御指導, 御鞭撻を賜わ り，御校閲の労を賜わった恩師中山種秋教授に深甚の謝 意を表します. 又教室の大森, 村上両講師に感謝致しま ఫ.

\section{文献}

1. Georg Bessler; Über den funktionellen Bau des Knochenkallus, Beiträge zur Anatomie Funktioneller Systeme, 442-443, (1933).
2. Mauer; Untersuchungen über funktionelle Anpassung der Wirbelsäule bei Skoliose, Beiträge zur Anatomie Funktioneller Systeme, Bd I, 412, 420, (1933).

3. 中山種秋; 骨分裂線特に不整裂線の意義：九州画会 誌, 11 (1)， 1-4，(1957).

4. 長谷部言人; 人の睪丸白膜及眼球強膜の裂向飞就 て : 東北医学誌, 1 (1)，67-72，(1916).

5. 福井元之輔; 皮㾝結締組織装置の構築飞就て：医学 研究, 10 (4), 1-126, (1936).

6. 坂口幸介; 骨維密質の構築に就て : 医学研究， 9 (3), 1-92, (1935).

7. 橋本元明; 口蓋粘膜並びに歯槽粘膜の鐻隙線に関す る研究：金沢大学医学部解剖学教室業績集52, 214.1, (1954).

8. 士佐純生; 哺乳動物眼球強膜の分裂線に関する比較 解剖学的研究: 熊本医学会誌, $30(7), 67-81$, (1956).

9. 大森忠雄; 卵殼膜分裂線の比較解剖学的研究 : 九州 歯会誌， 11 (3)，1-4，(1957).

10. 阿部 薰; 犬眼球強膜の発育に伴う分裂線の変化に 就て：熊本医学会誌，33（補 4)，268-277, (1959).

11. 阿部 菜; 胎児皮膚の分裂線と毛流々の関 係に就 て : 九州菊会誌, 13 (1)，23-42，(1959).

12. 鶴丸正博; 犬の精巣鞘膜臓側板上に於ける分裂線の 年令的変化に就て：九州歯会誌，13（2）, 59-68, (1959).

13. 鶴丸正博；犬の卵巣䇾上に現方れる分裂線の年令的 変化に就て：九州齒会誌，14（1）, 217-221， (1960).

14. 松隈荘一; 犬の脾被膜分裂線の加令的変化に就て： 九州䨑会誌, 14 (2), 25-36, (1960).

15. 沖重豊美; 犬胃墏膜分裂線の年令的観察 : 九州歯会 誌, 14 (2)，37-44，(1960).

16. 野見山滋光; 数種哺乳動物に抽ける舌粘膜固有層の 分裂線江ついて：九州歯会誌，22（1），37-42, (1968).

17. Akitatsu SHIMAMURA; A STUDY ON THE LYSSA (Tollwurm): J. of Kyushu Dental Society. 10 (2), 1-16, (1956).

18. MALCOLM E - MILLER; ANATOMY OF THE DOG, W. B. Saunders Company, philadelphia - London, 154, (1967). 
19. 加藤嘉太郎; 学蓄比較解剖学図説 1 巻, 187, 養賢 堂, (1961).

20. 小西 要; 臨床獣医便覧, 養賢堂, 175, (1949). 附図 I図（1）（2）（3）（4）（5）（6) (7) (8) (9) (10) (11) (12)
(13) (14) (15) (16)

II 四 (1) (2)

项図

IV図 (1) (2) 
$-10-$

I 図(1)
舌 背

No. 1

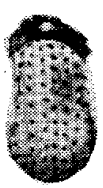

䒜尖 部

右 側 部

左 側 部
胎
仔
60
日

№. 2

胎
仔
60
日

No. 8

生
後
10
日
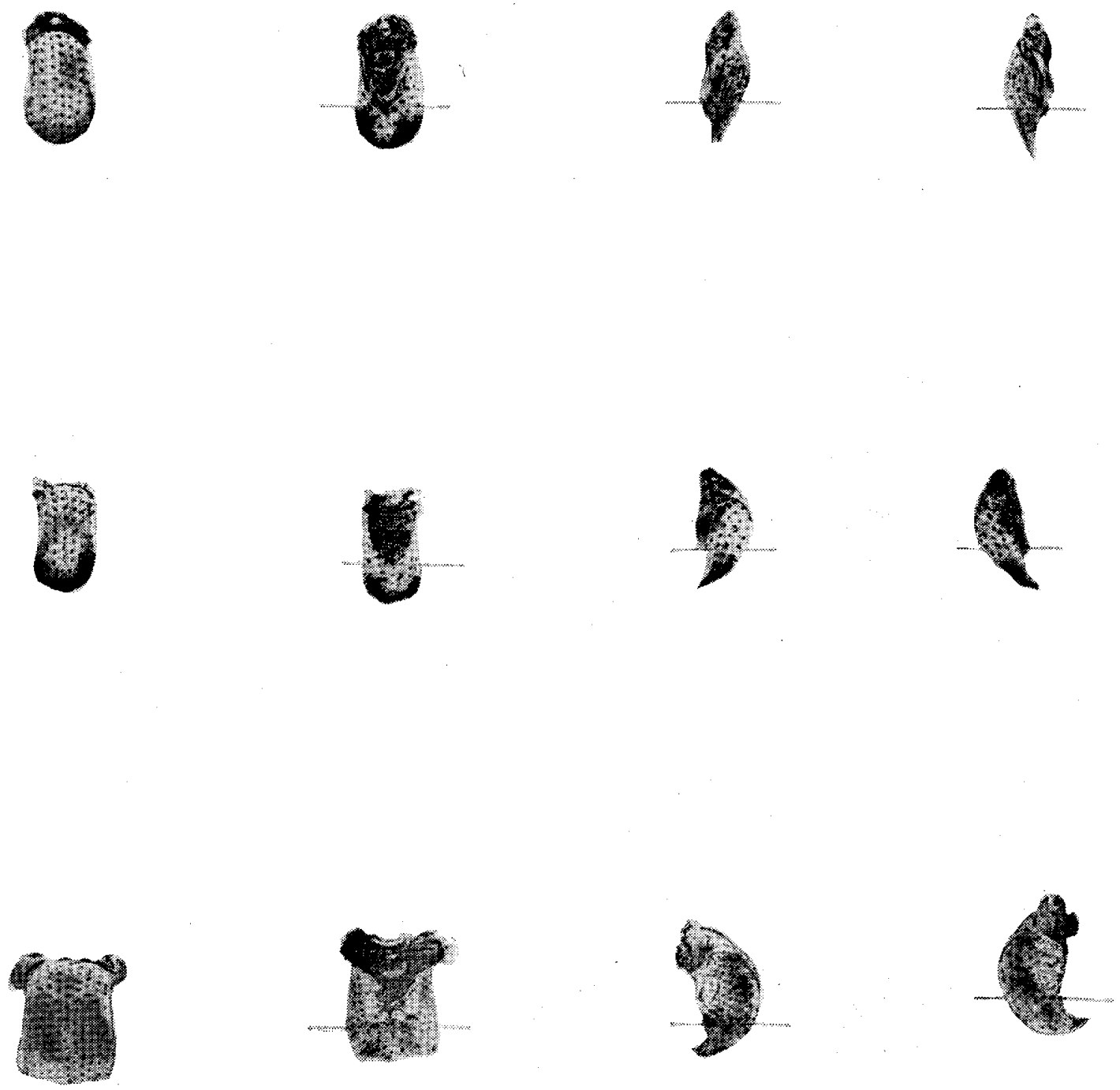

No. 9

生
後
10
日
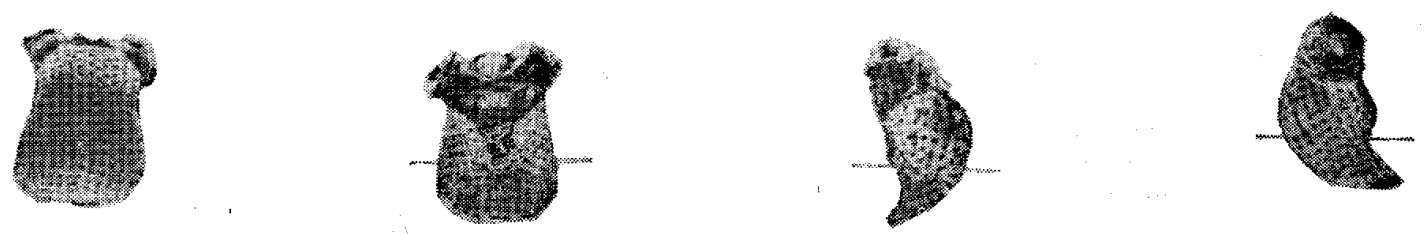
I 困(2)

$$
\text { 舌背舌尖部右 侧 部倒 部 }
$$

No. 10

生

後

10

日
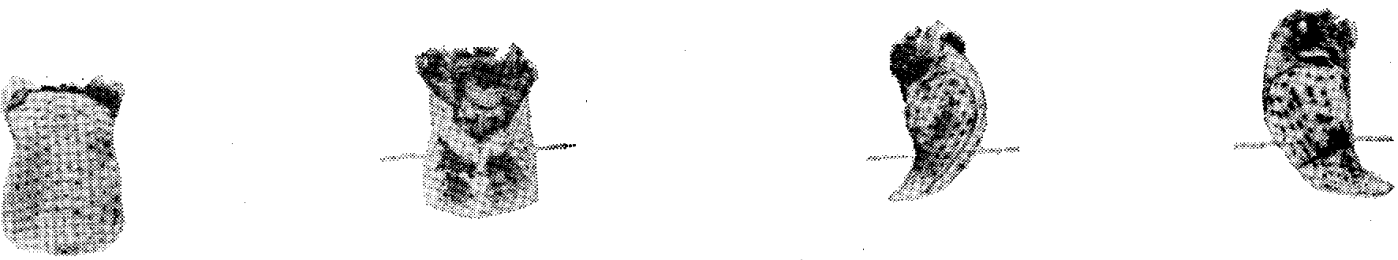

No. 11

生
後
20
日
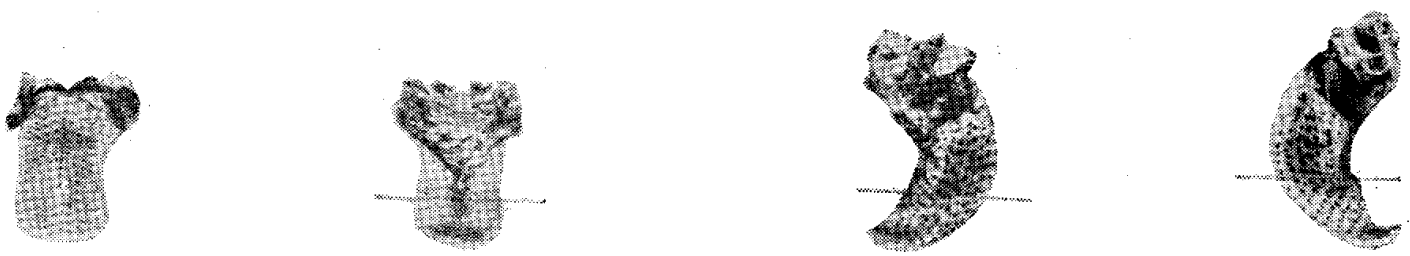

No. 12

生
後
20
日
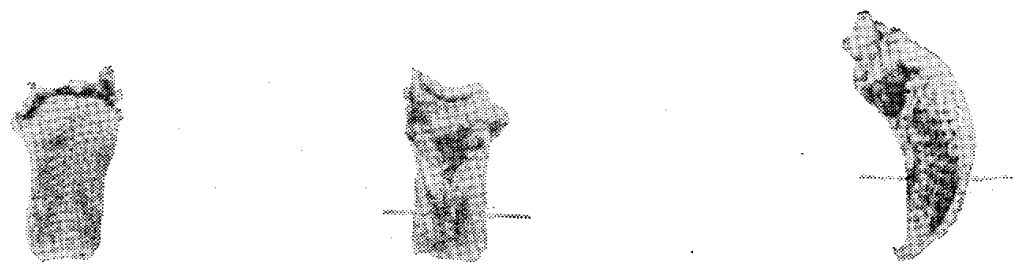

No. 13

生
後
20
日
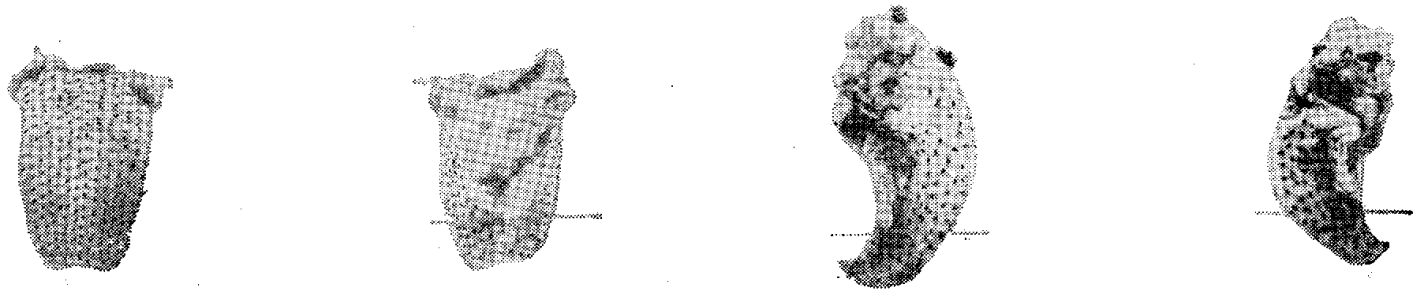
I 図(3)

再背舌尖部右 侧 部左 侧

No. 14

生

後

30

日
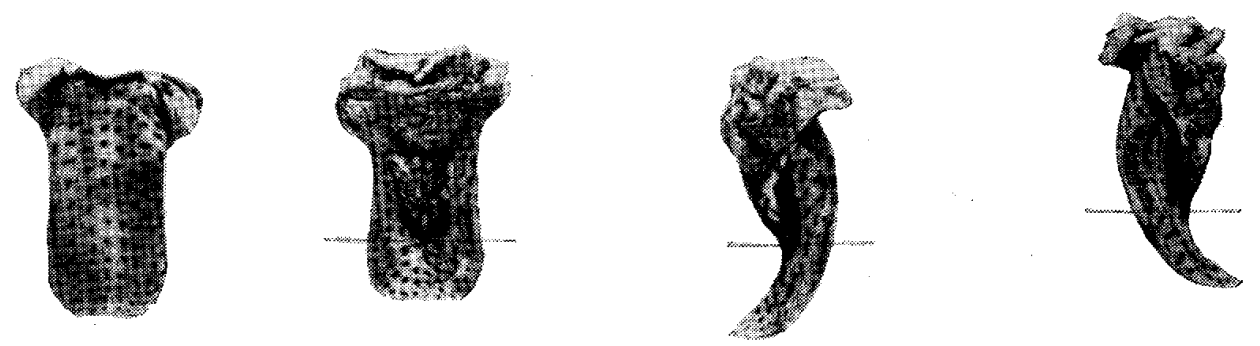

No. 16

生

後

30

日
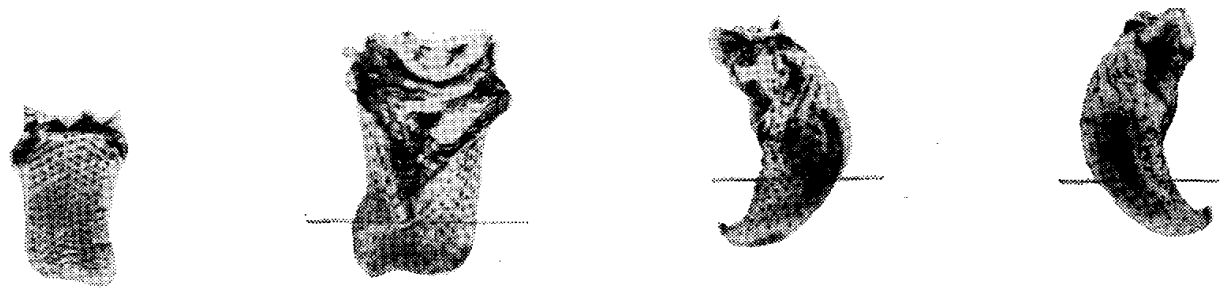

No. 18

生
後
30
日
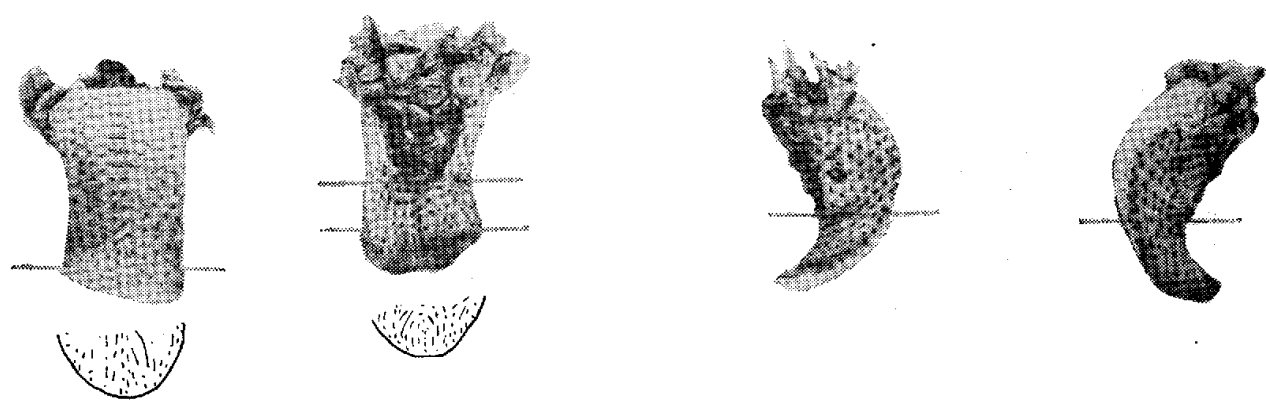

No. 20

生
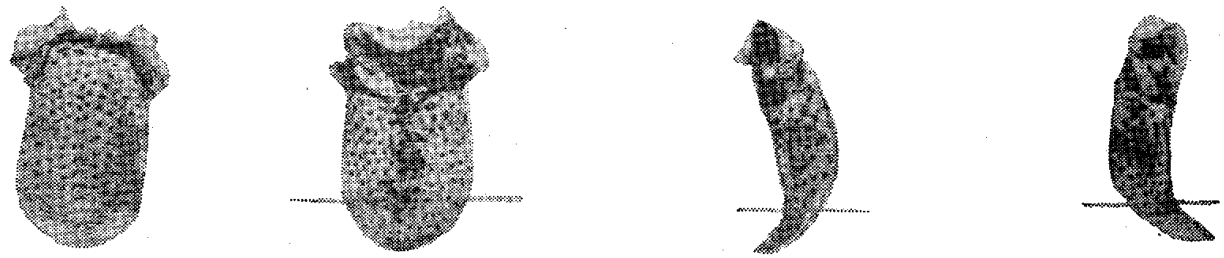


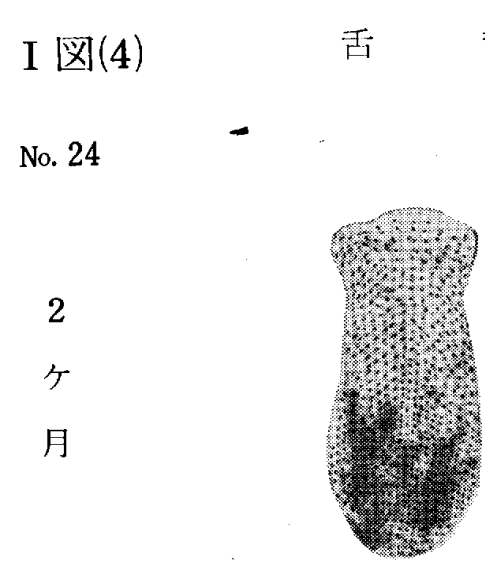

韭 尖 部

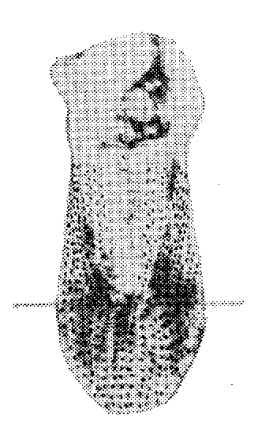

No. 25

2
ケ
月
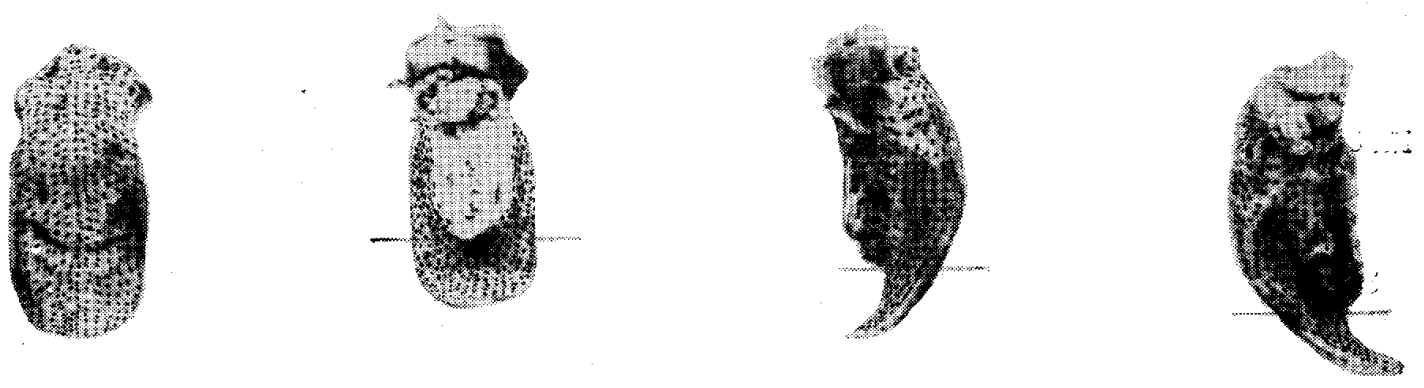

No. 26
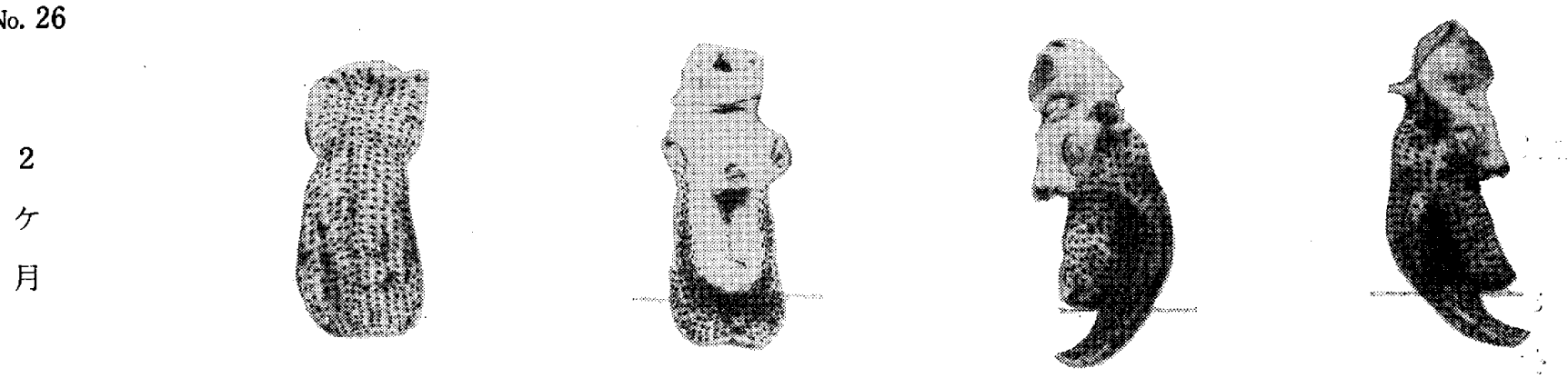

No. 27

2
ケ
月
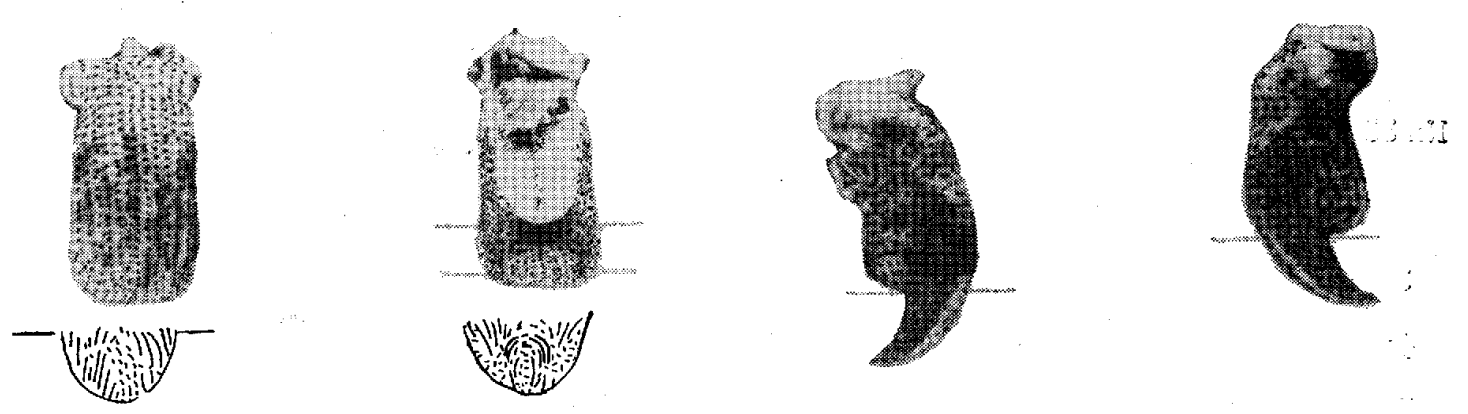


\section{I国(5)}

No. 30

3

ケ

月
舌 背
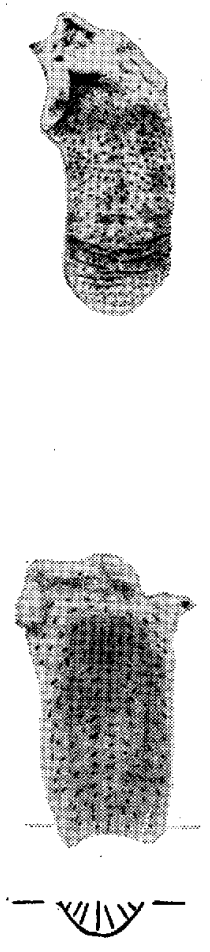

No. 31

3
$ケ$
月

No. 32

3

ケ

月
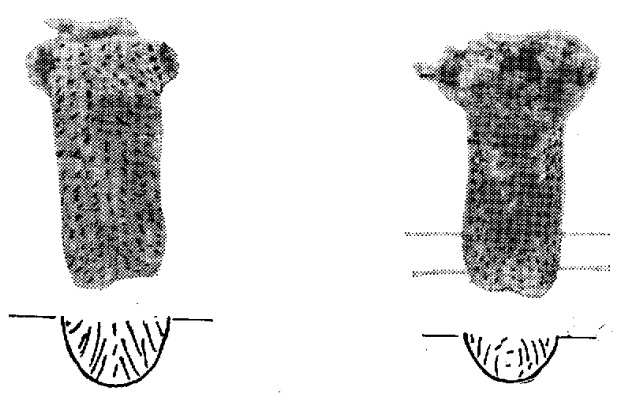

$-\sqrt{1}-1) 1 y^{2}$
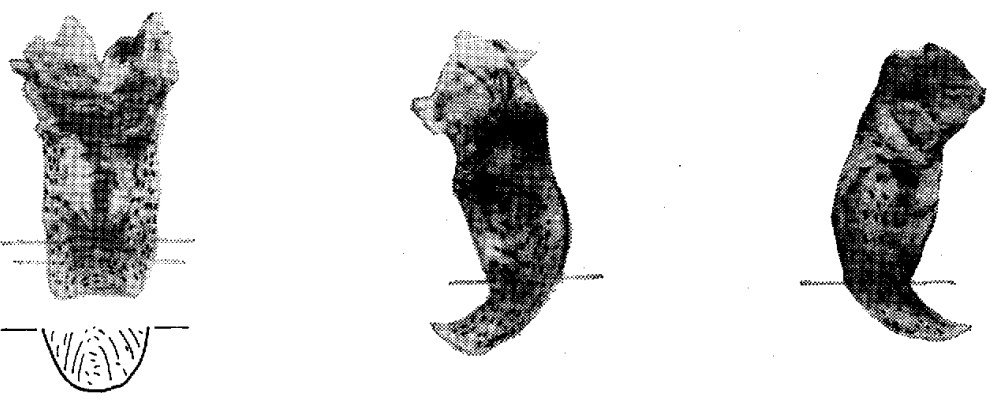

右 側 部

左 側 部
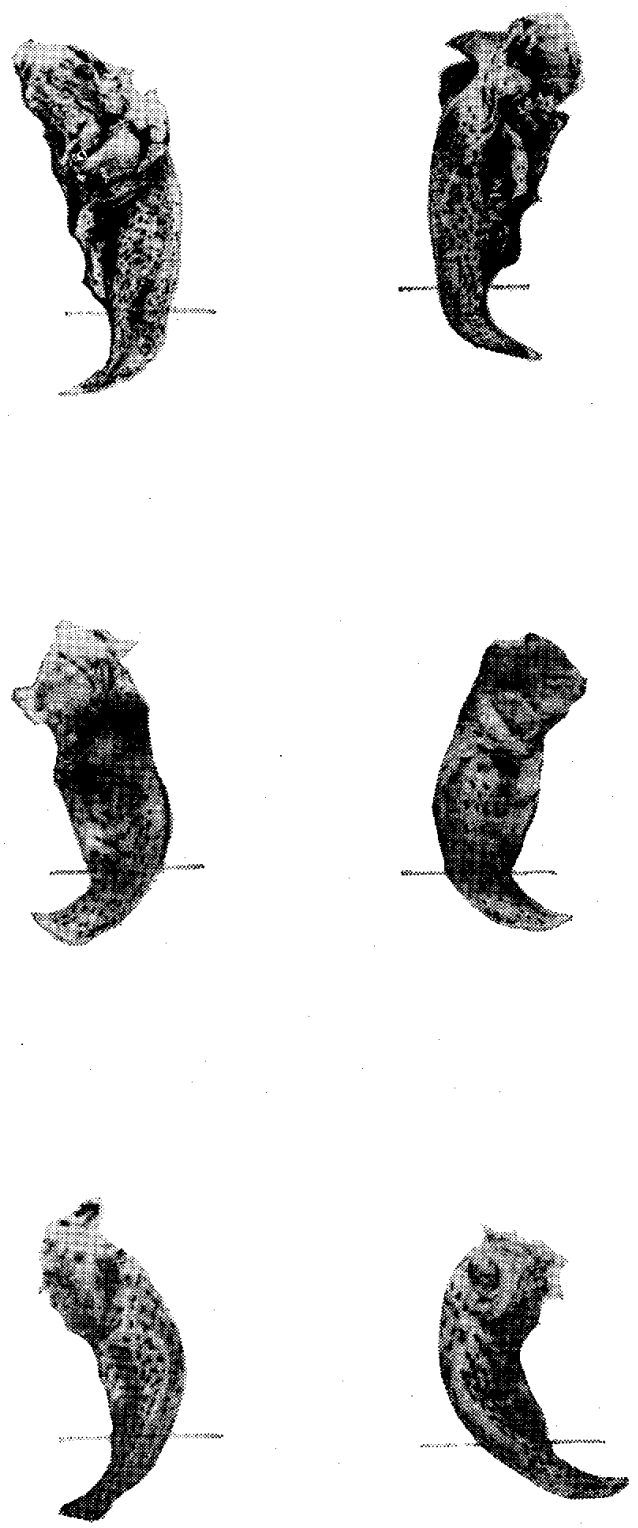

No. 33

3

ケ

月
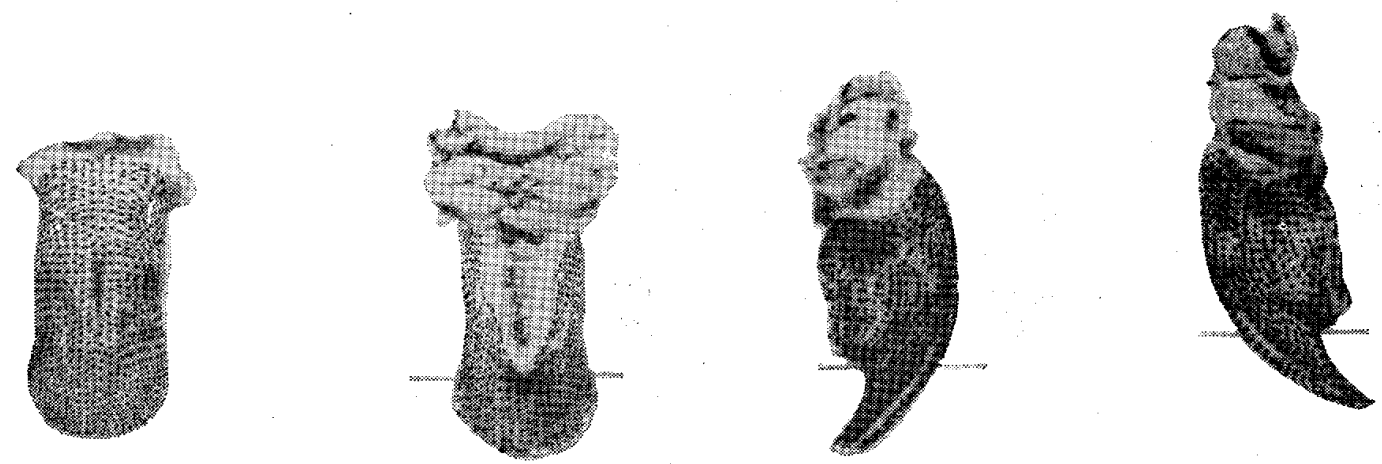
I 図(6)

舌背舌 尖 部

右 側 部

左 側 部

No. 35

4
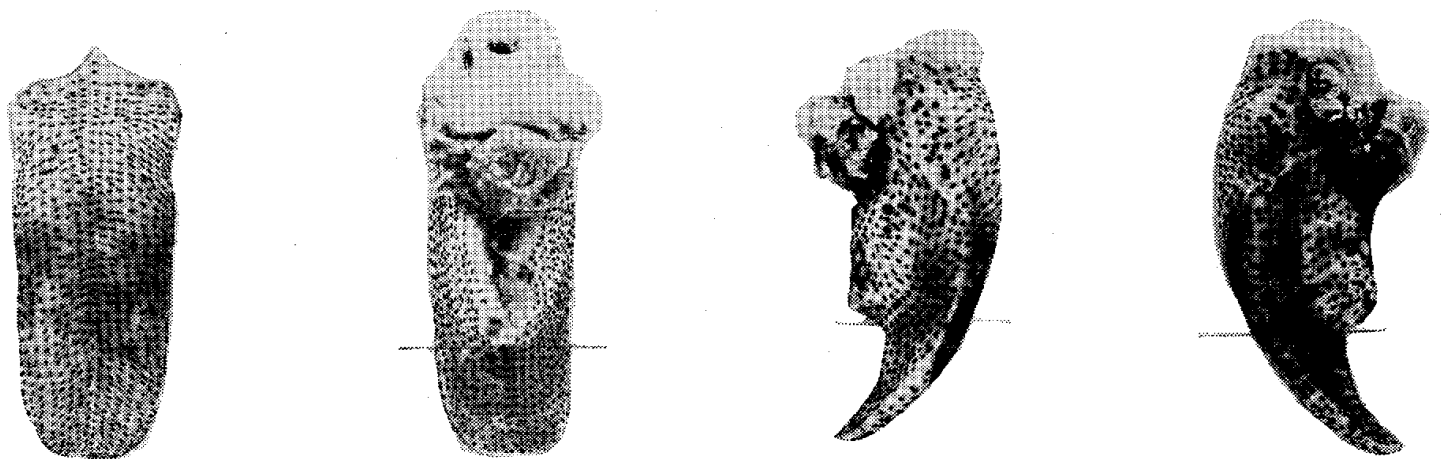

No. 36

4

ケ

月
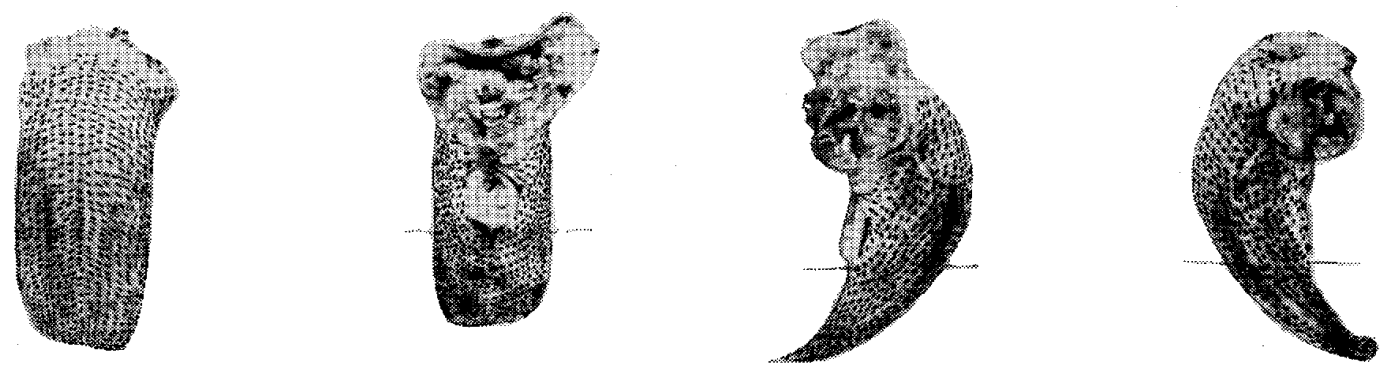

No. 37
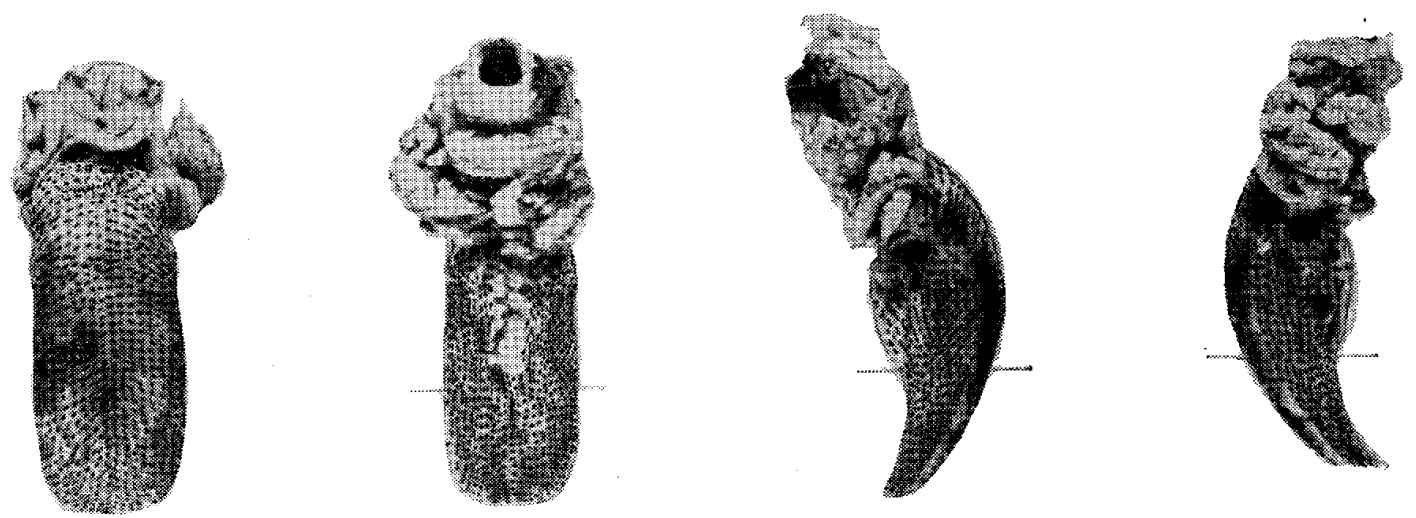

No. 38

5

ケ

月
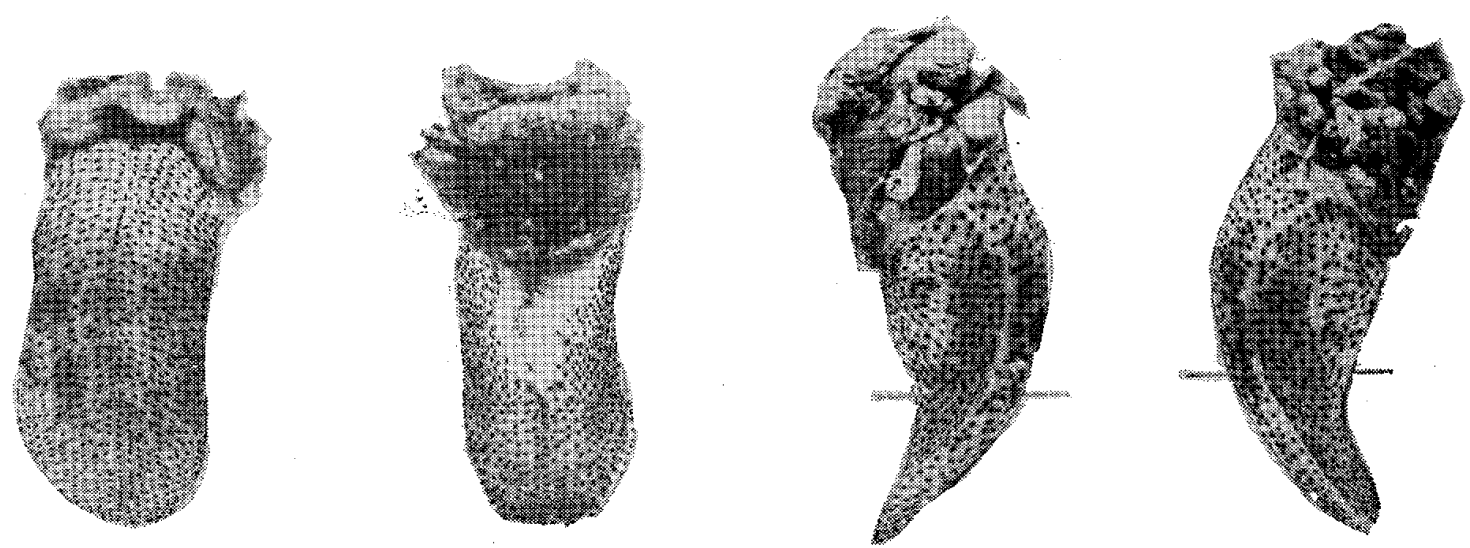
I 図(7)

舌 背

No. 39

No. 40

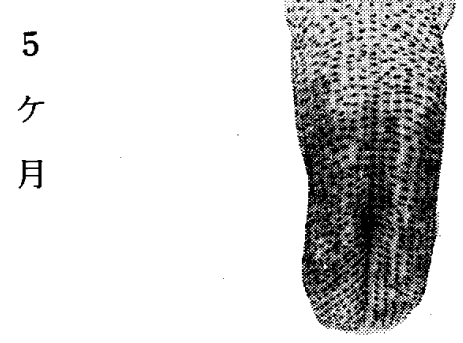

No. 41

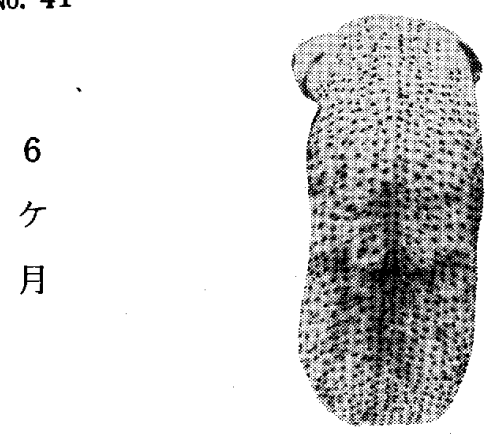

No. 42

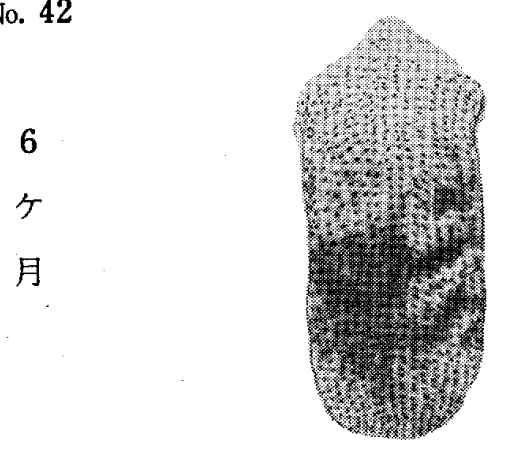

舌尖部

右 側 部

左 側 部
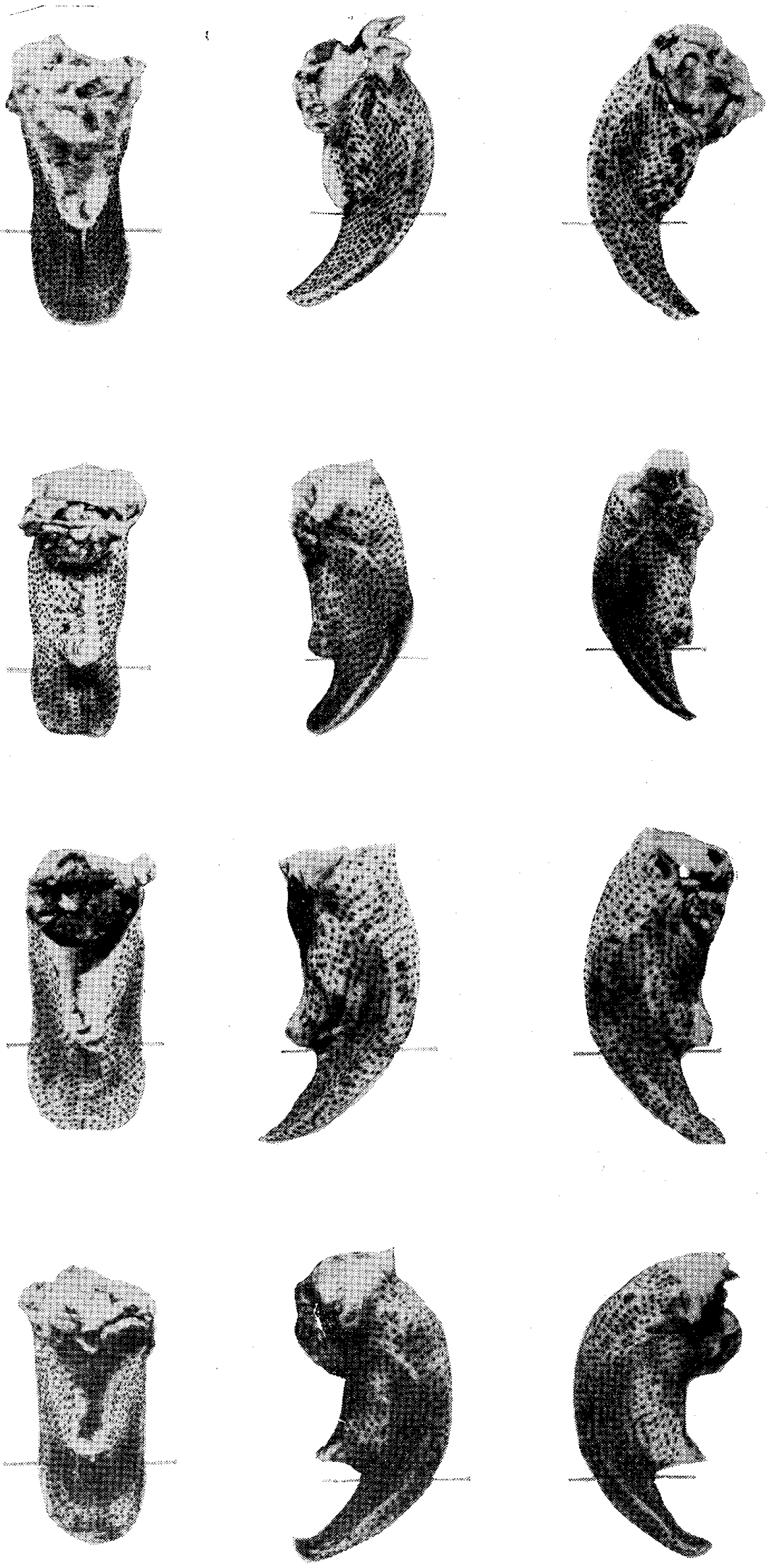
I 図(8)

No. 43

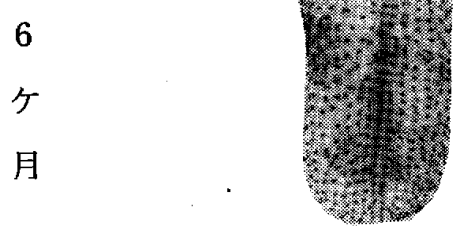
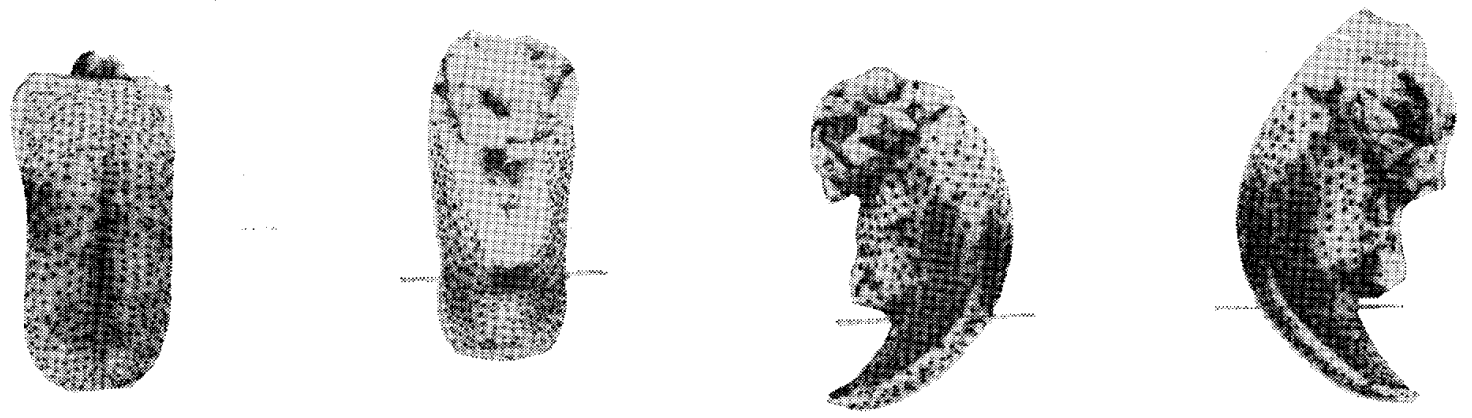

No. $44^{\prime}$

No. $45^{\prime}$
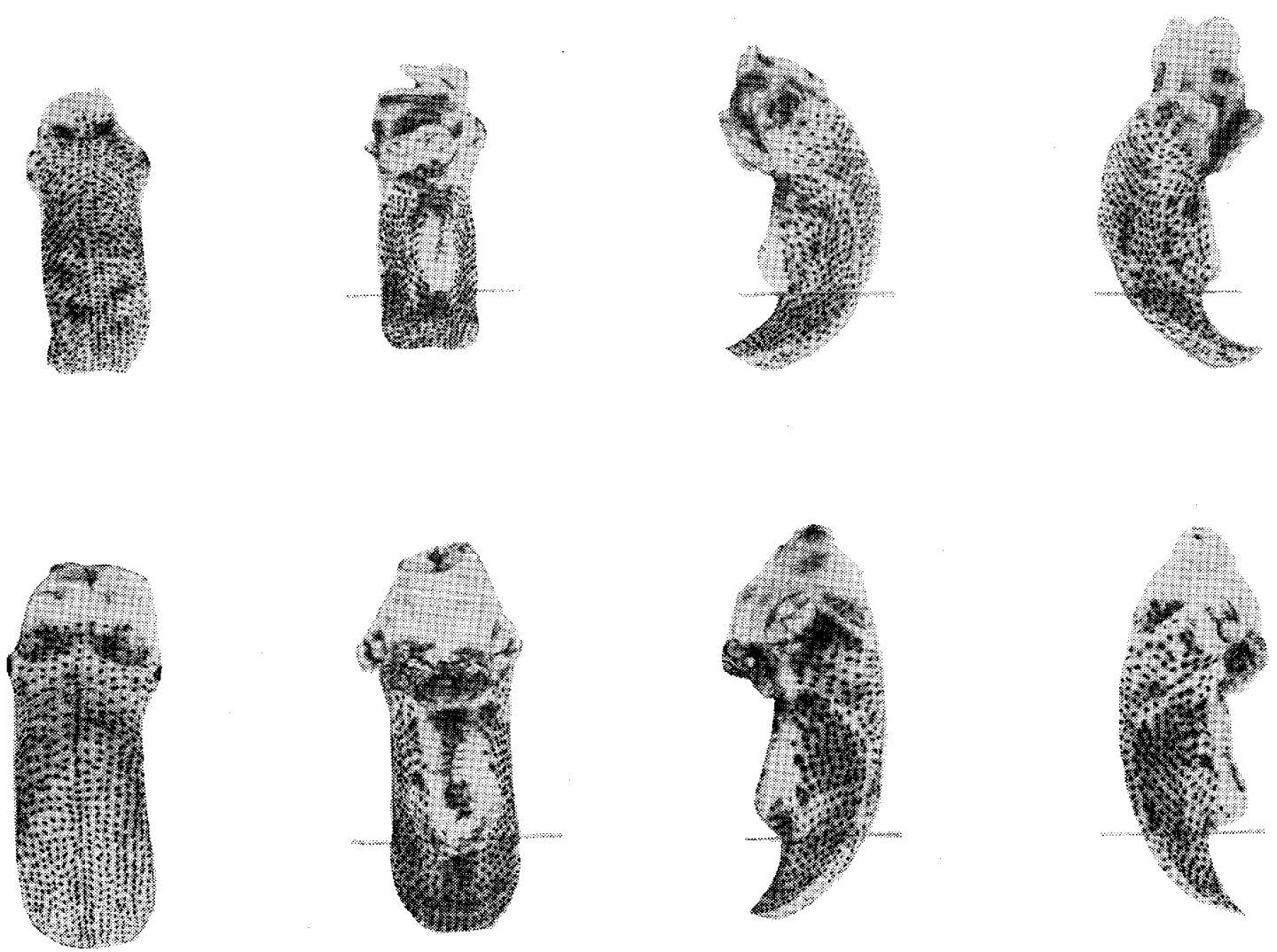

No. $46^{\prime}$

7

ケ

月
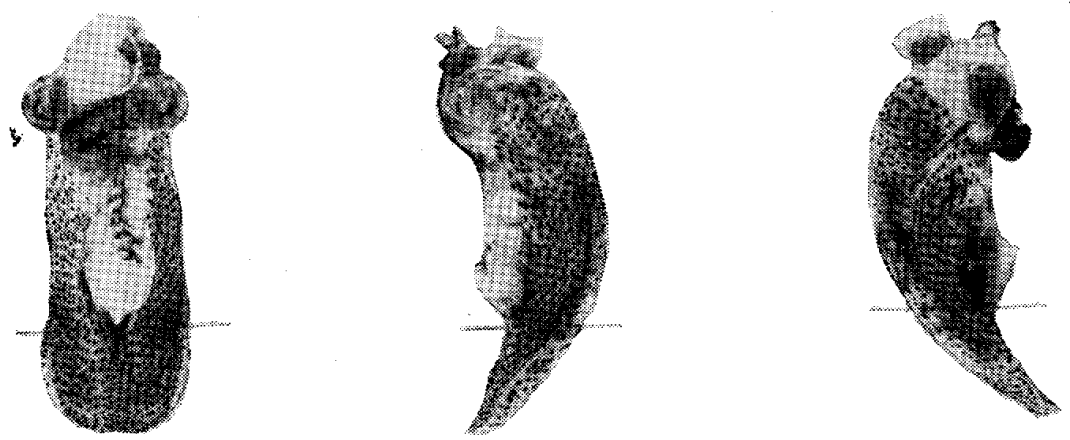
I 図(9)
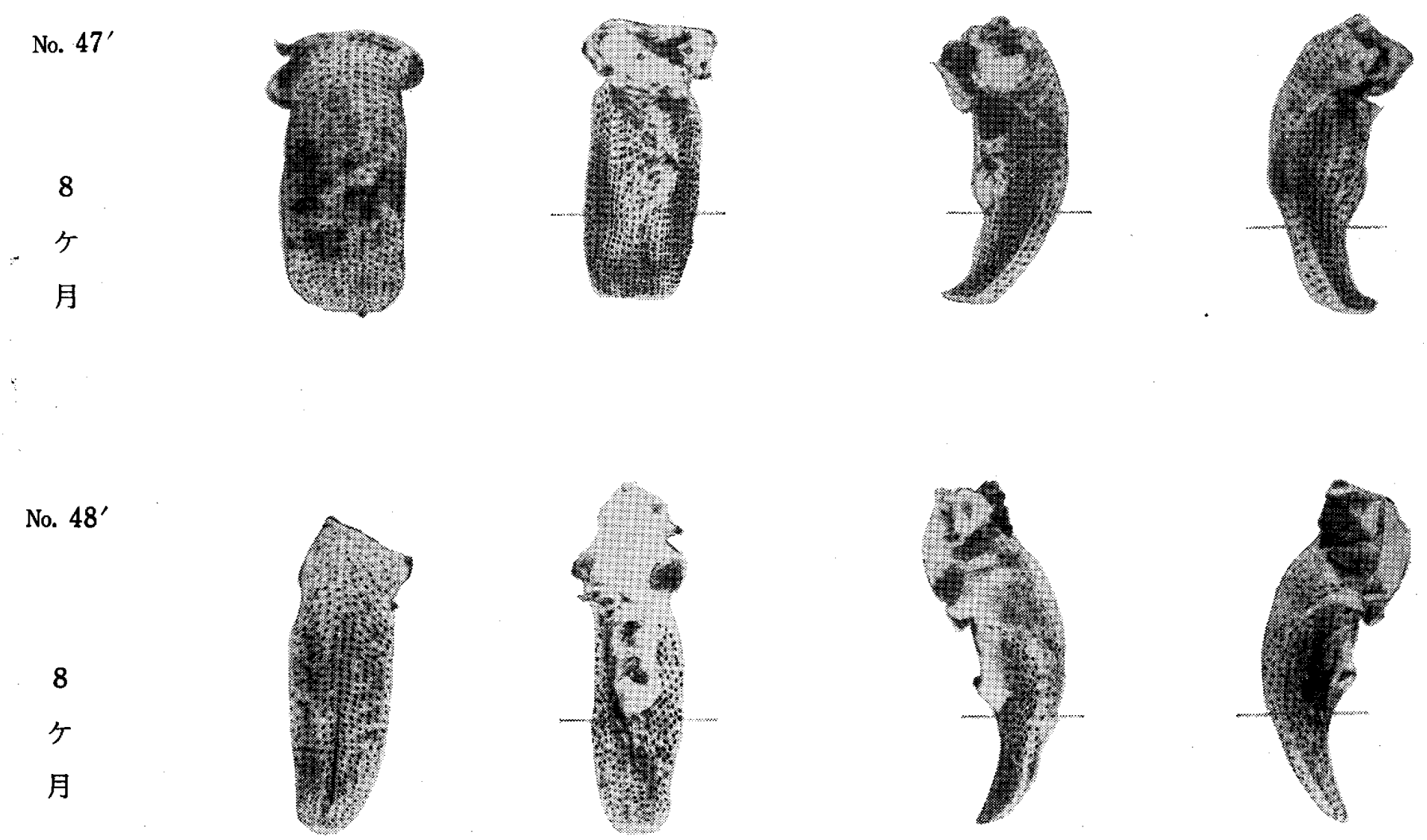

No. $49^{\prime}$
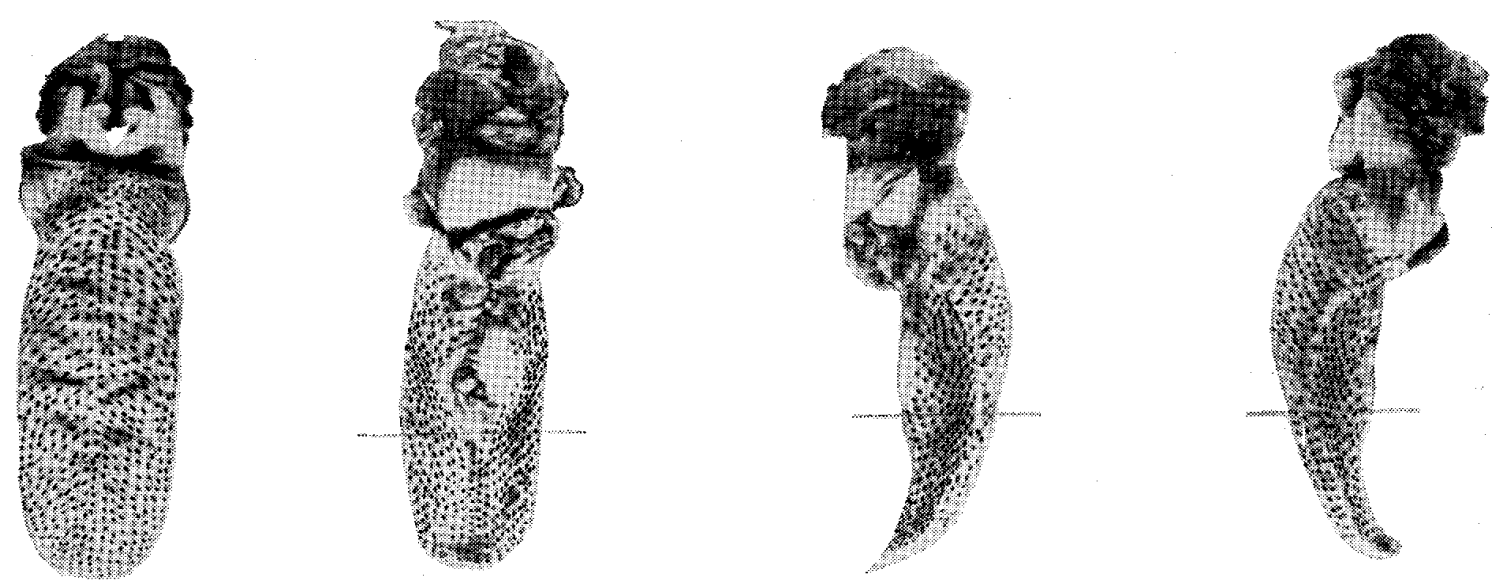

No. $51^{\prime}$
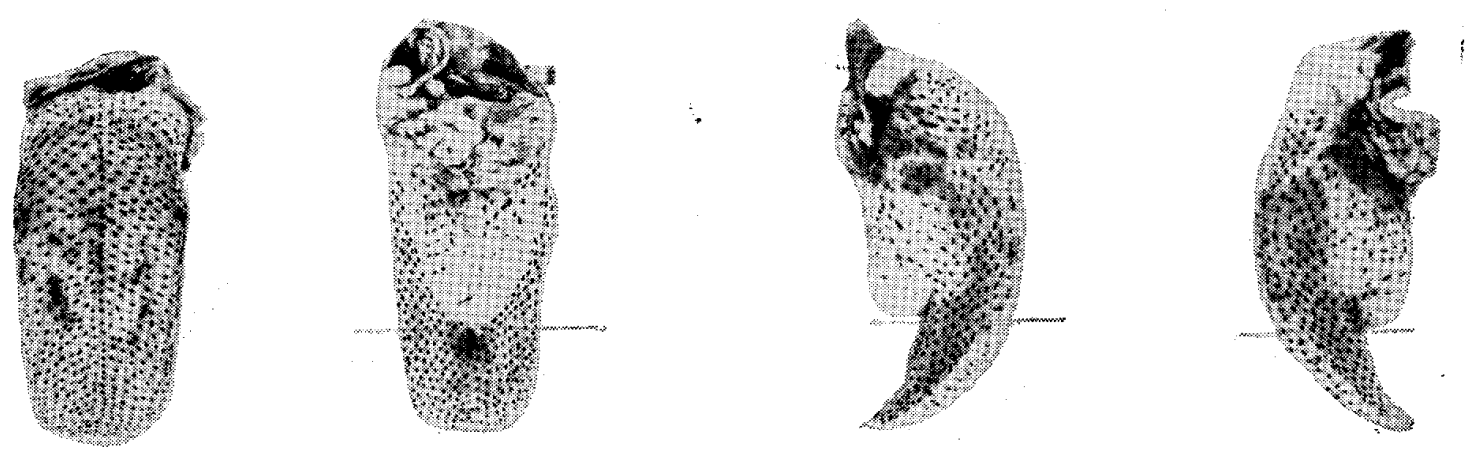
I 困(10)

舌许

No. $52^{\prime}$

10

ケ

月

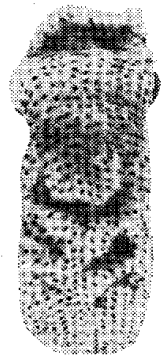

No. $53^{\prime}$

10

ケ

月
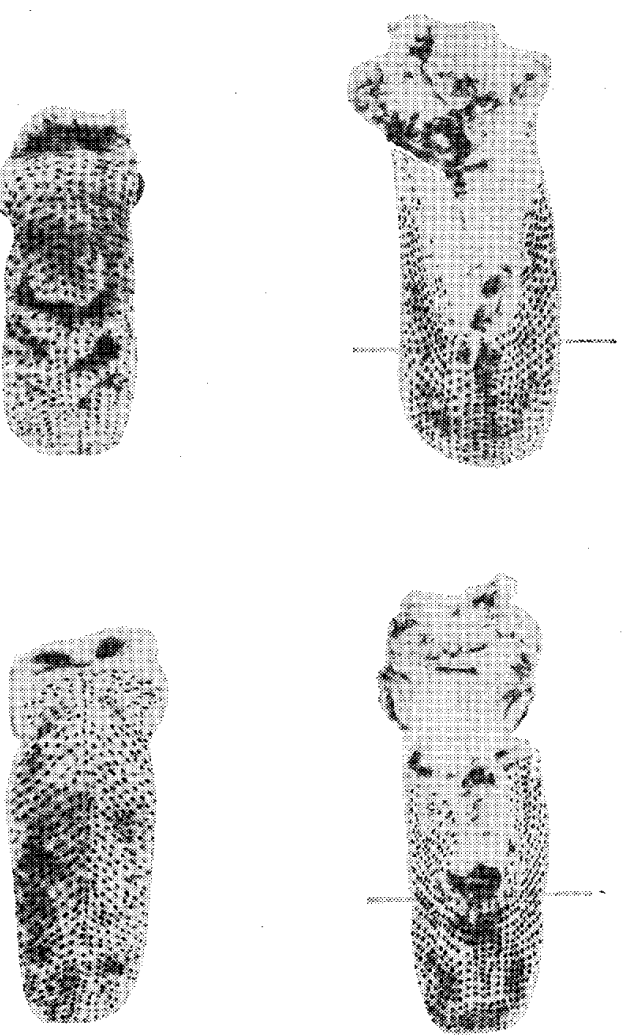

No. $54^{\prime}$

11

ケ

月

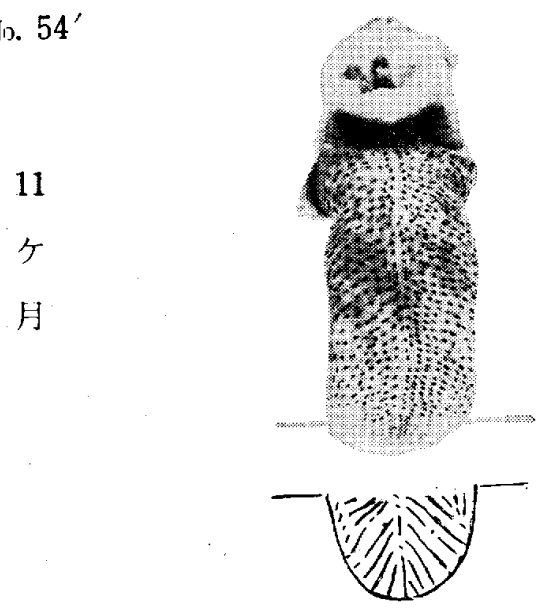

No. $55^{\prime}$

11
ケ
月

$$
\text { 舌 尖部 }
$$

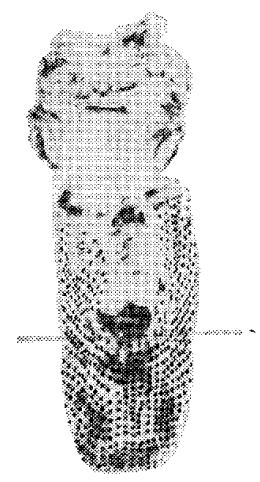

右 側 部
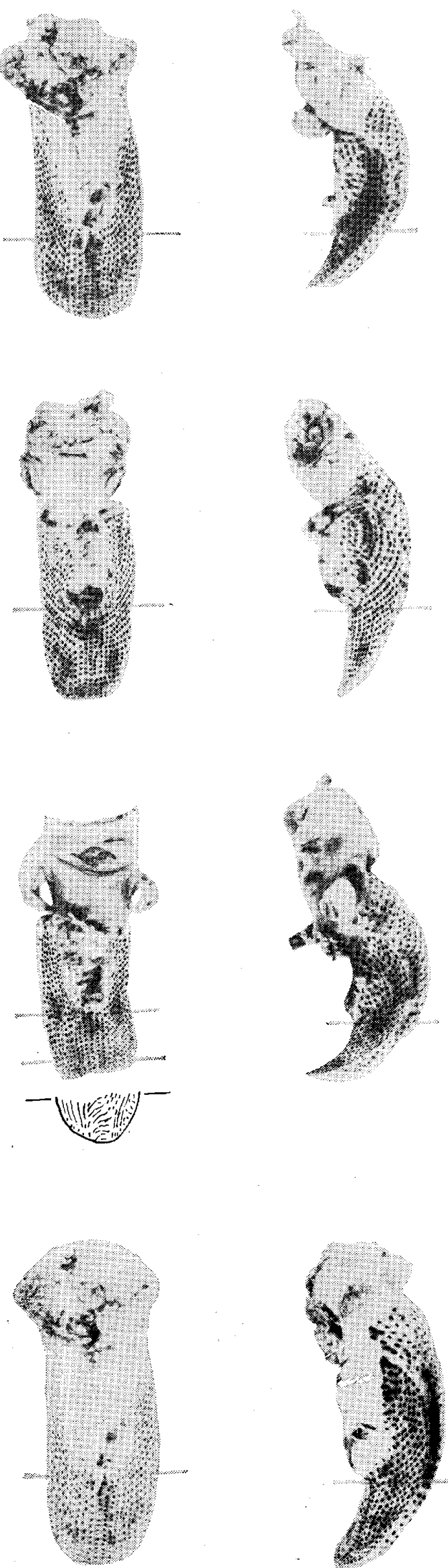

左 側 部
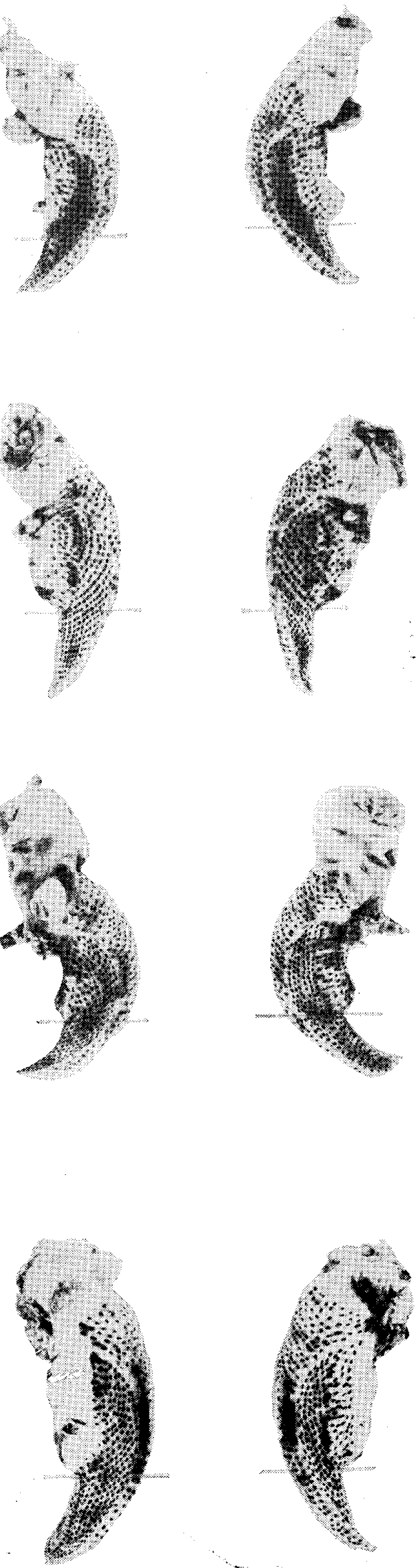
I 図(11)

舌 背

No. $56^{\prime}$

No. 46

1

No. 47

1

寸
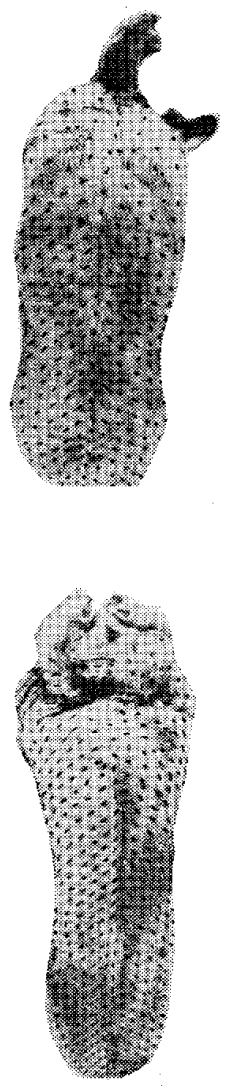

No. 48

1

寸

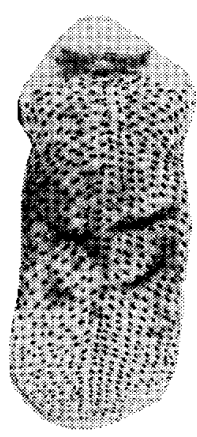

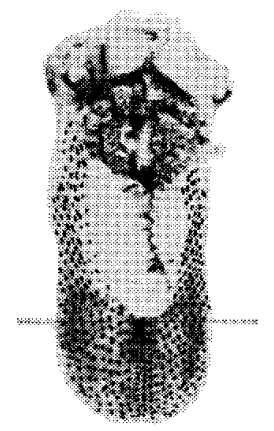
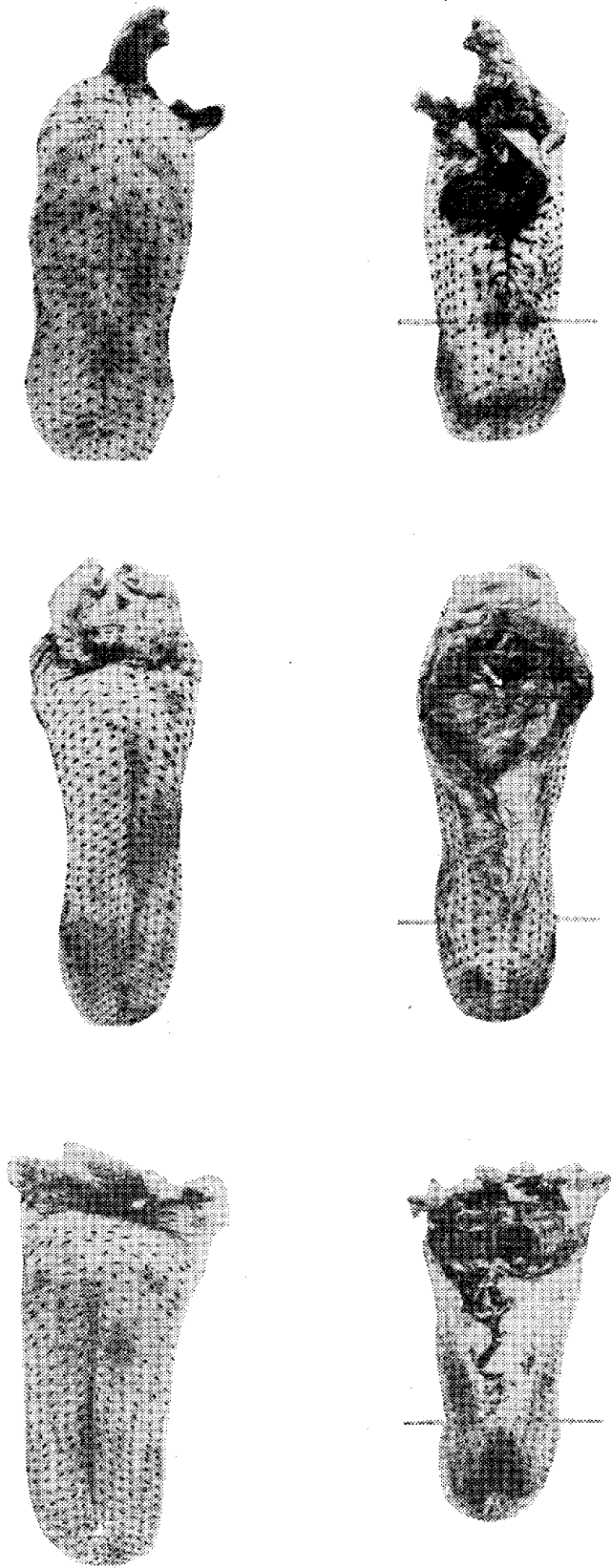

舌 尖 部

右 側 部

左 側 部
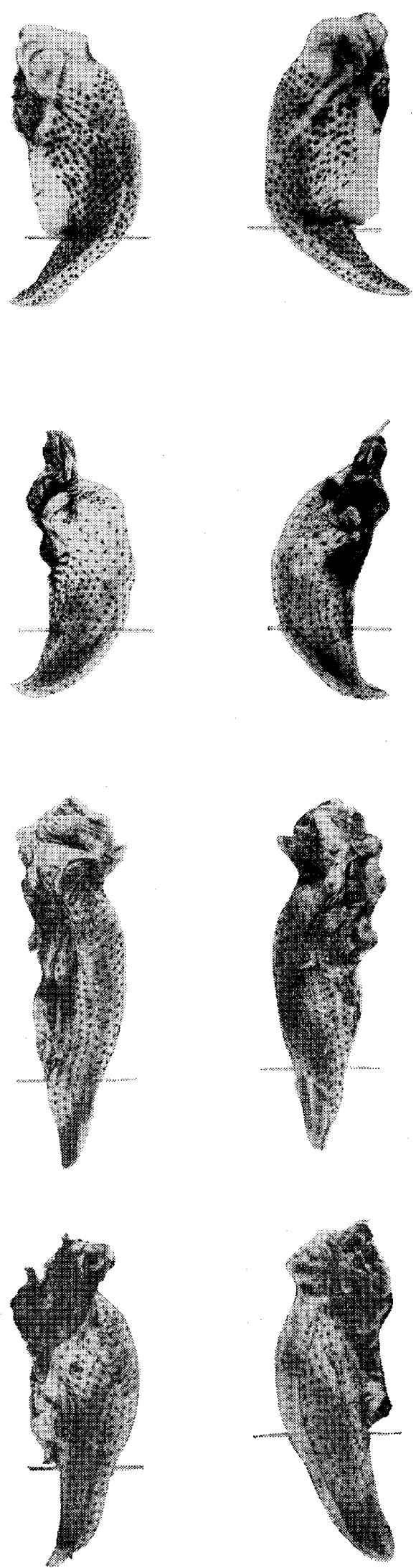
I 図(12)

舌 背

No. 49

1

才

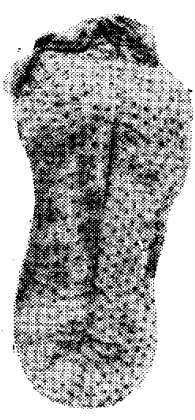

No. 50

1

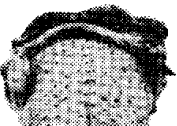

才

No. 51

1

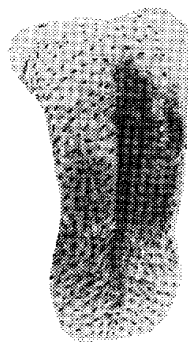

No. 52

2

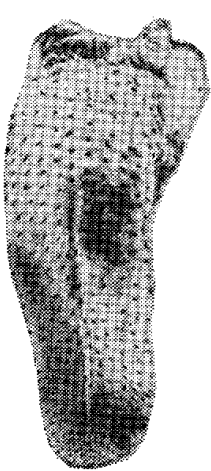

舌 尖 部
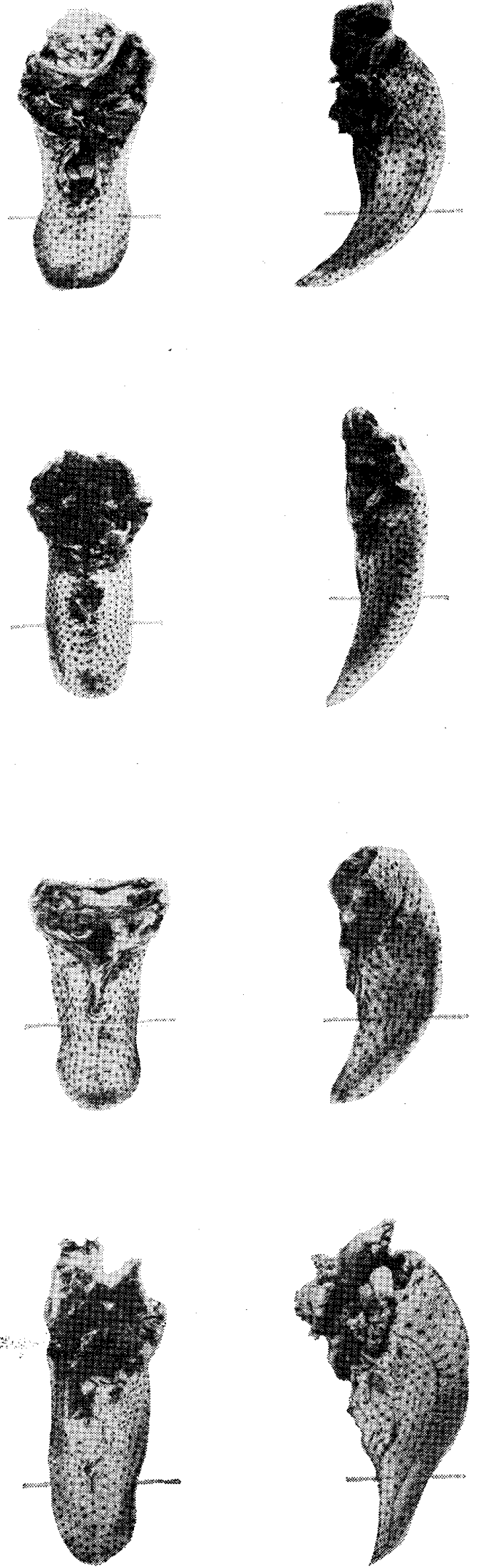

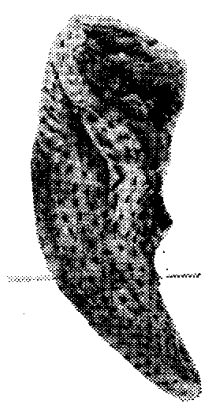

左 侧 部
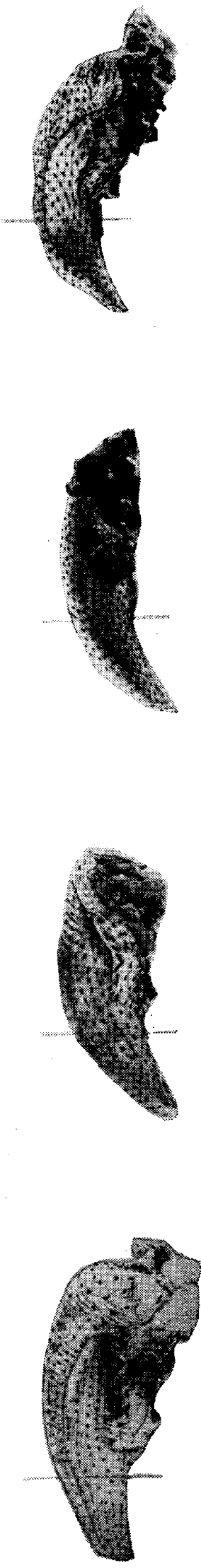
I 困(13)
舌 背
舌 尖 部
右 側 部
左 侧 部

No. 59

No. 64
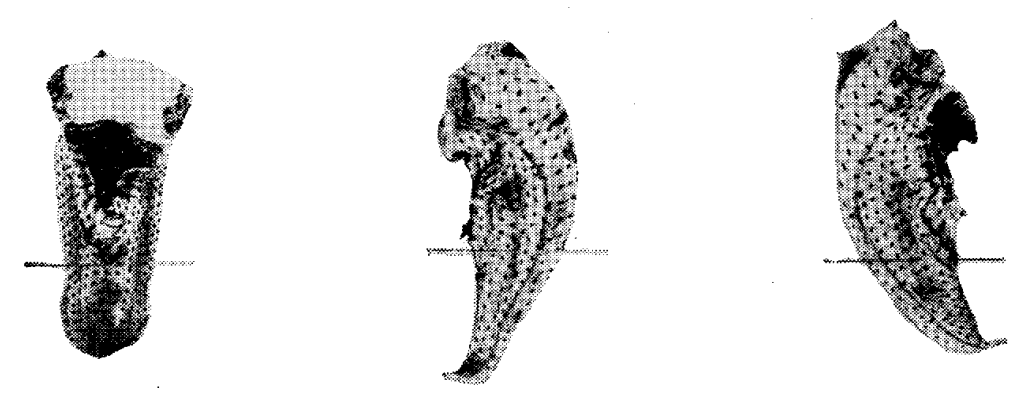

No. 64

2
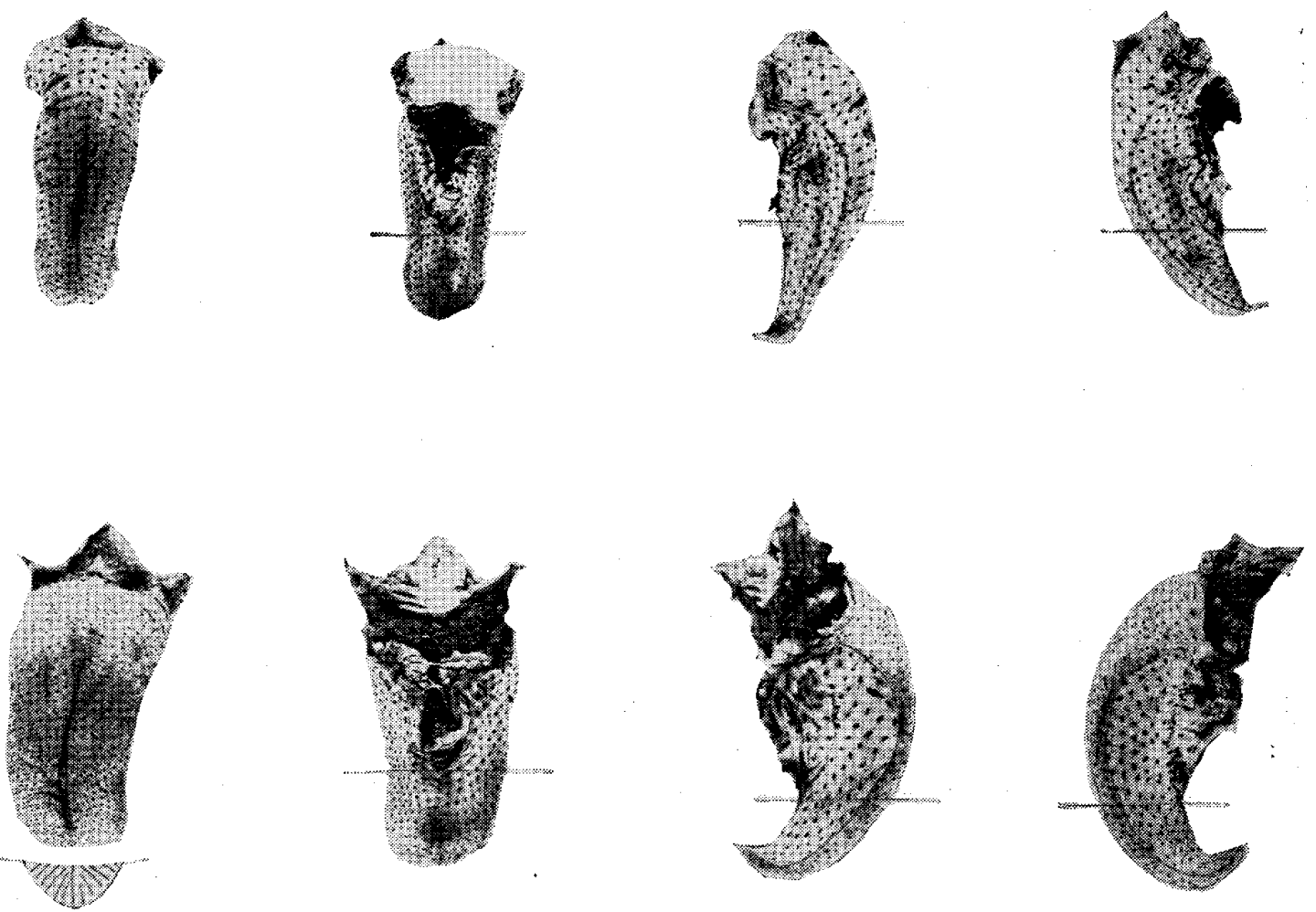

No. 66
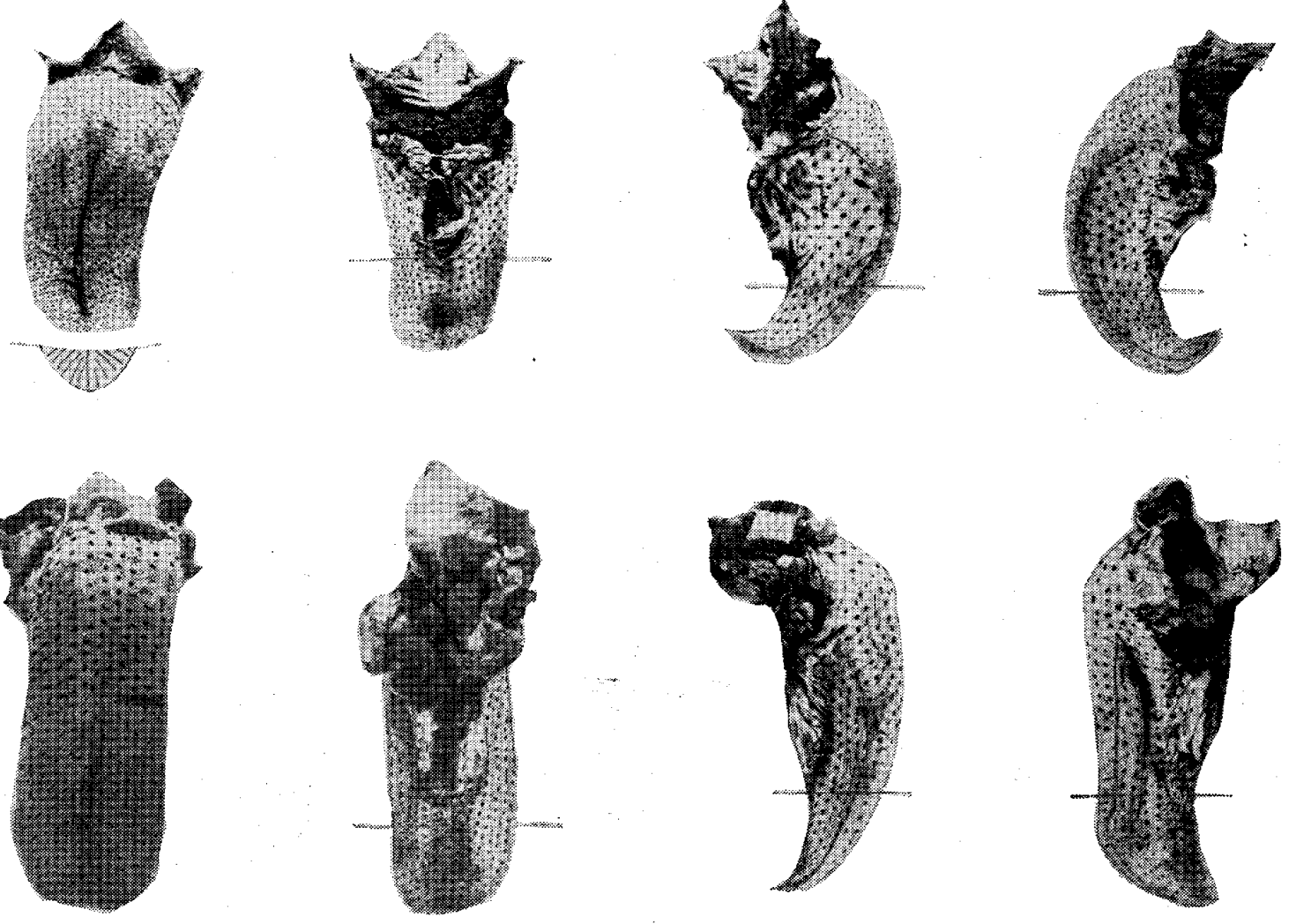

No. 67
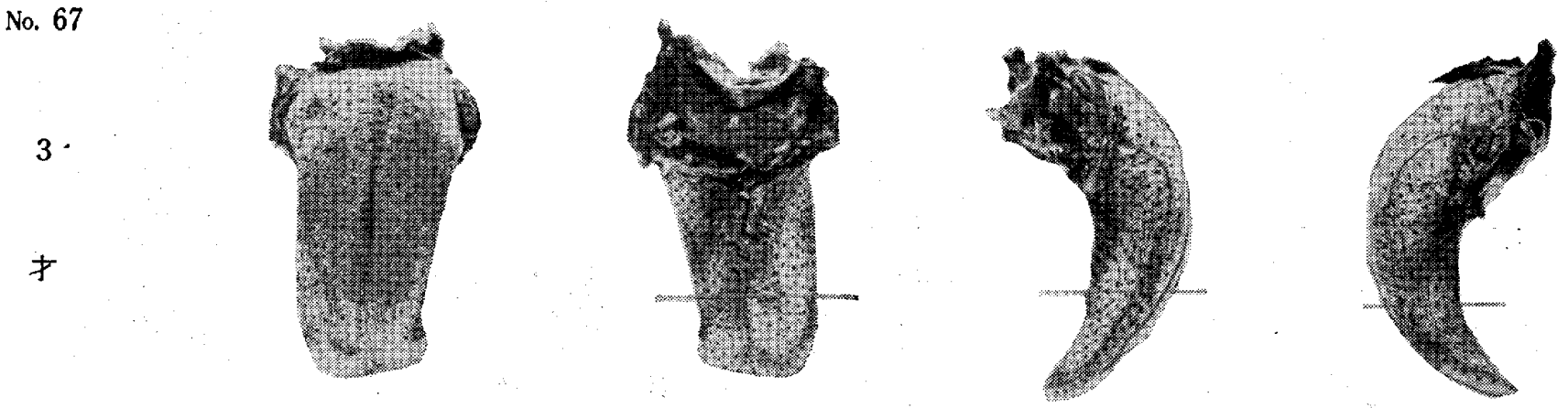
I 図(14)

吉猆

舌 尖 部

石 側 部

左 侧 部

No. 68

3
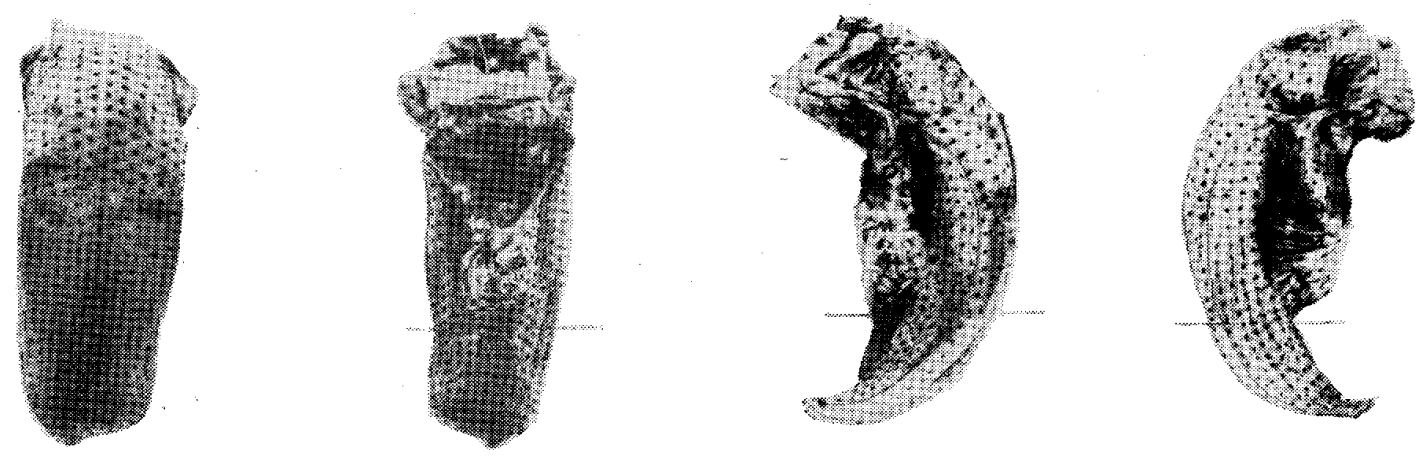

No. 69

4
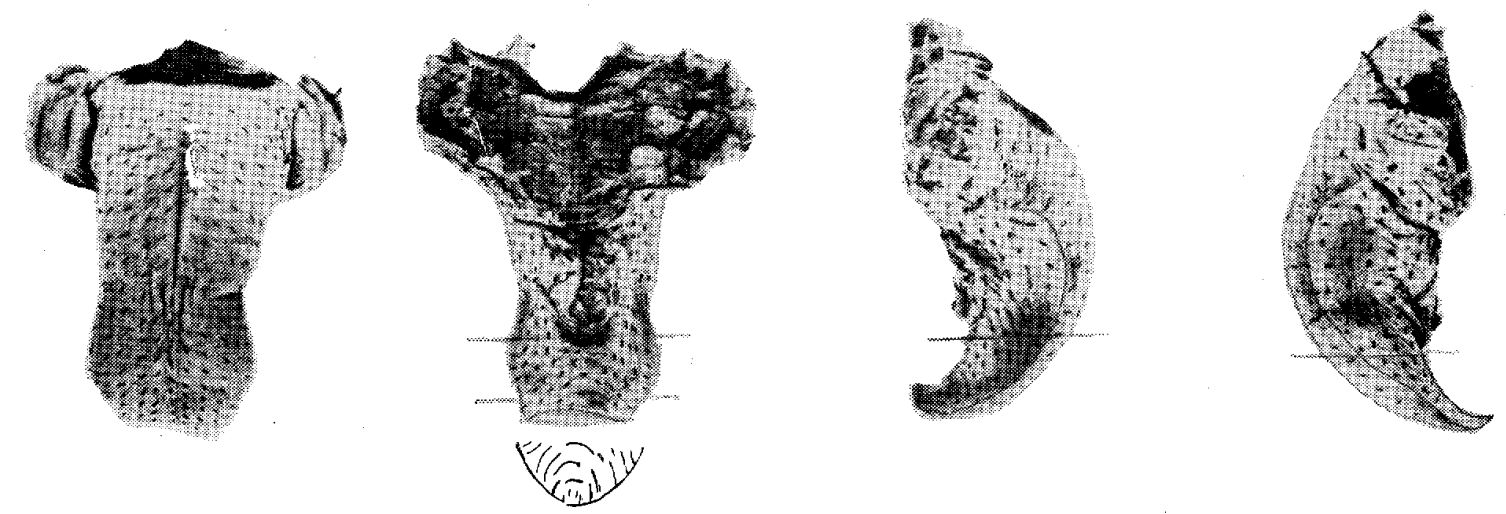

No. 71
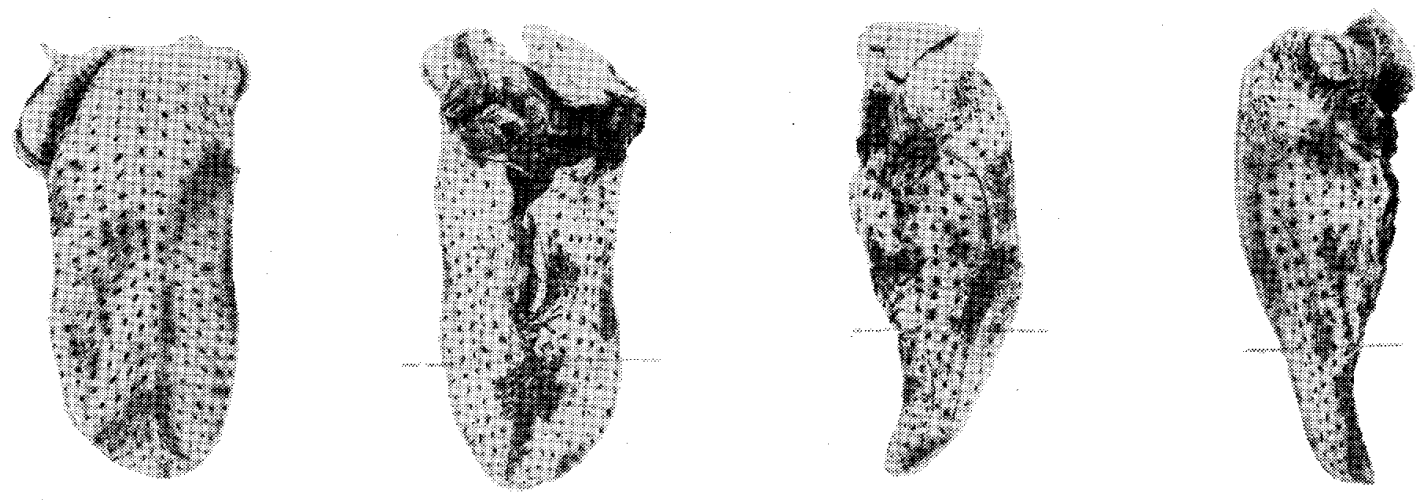

No. 72

4

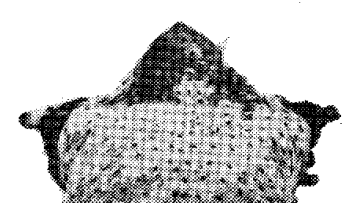

才
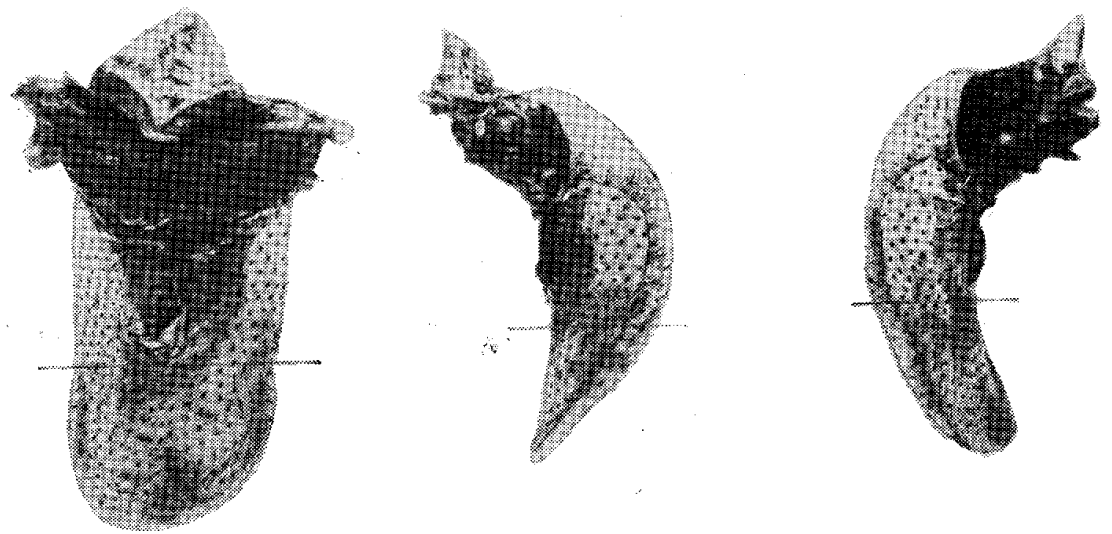
- 24- 犬の舌粘膜分裂線の加令的変化について

I 図(15)

舌 背

舌 尖 部

右 側 部

左 側 部

No. 74
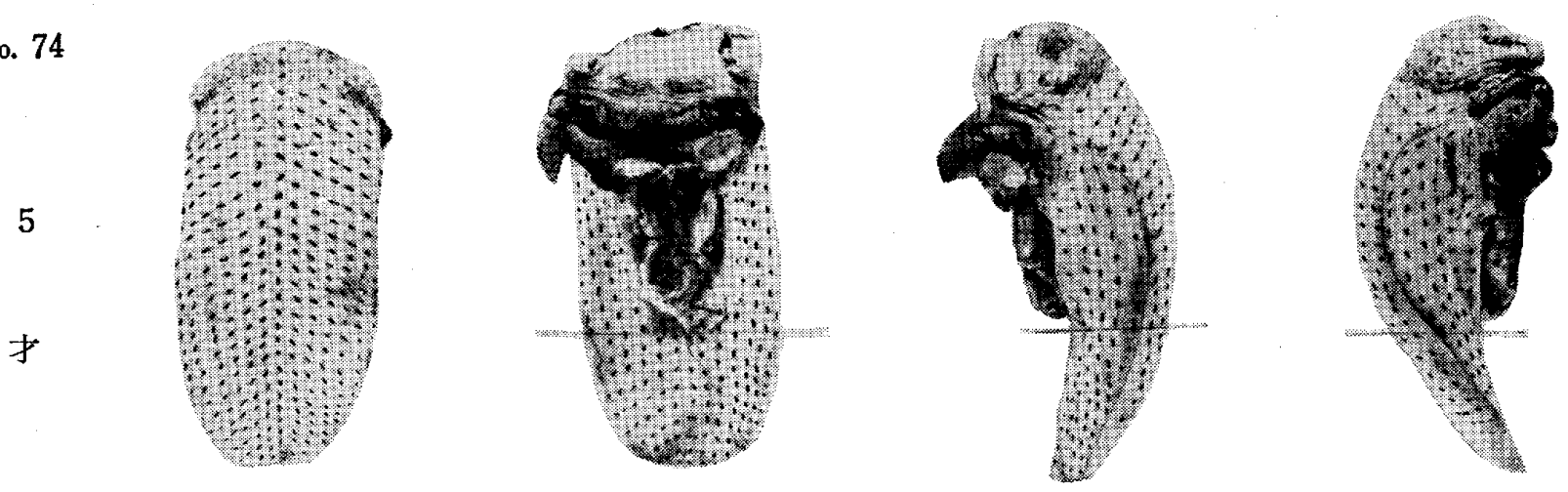

No. 75
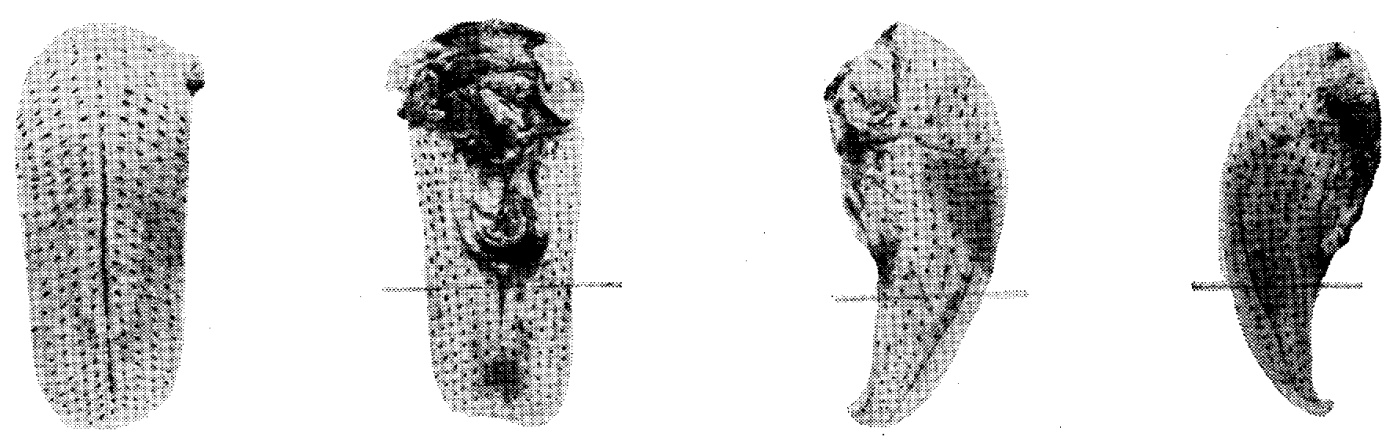

No. 77
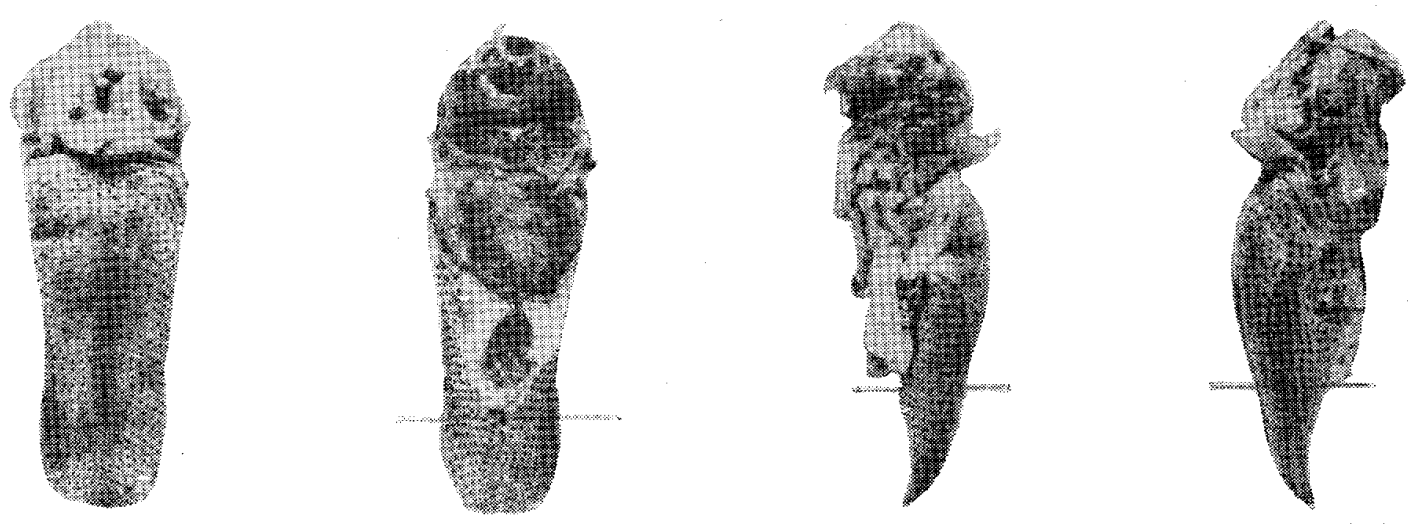

No. 78
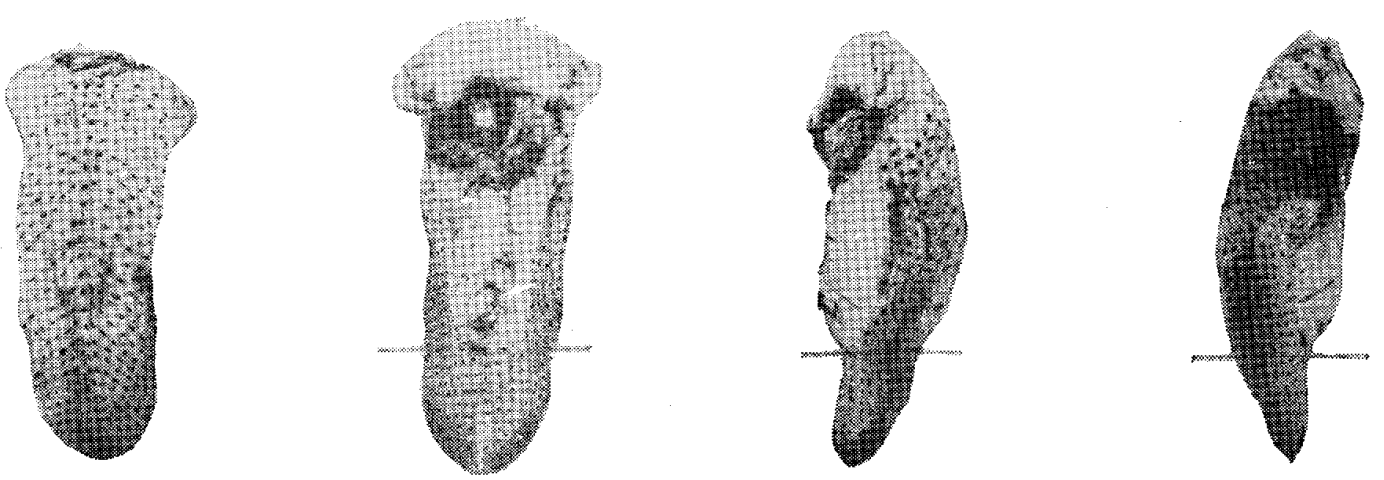
I 図(16)

舌 背

No. 79

6

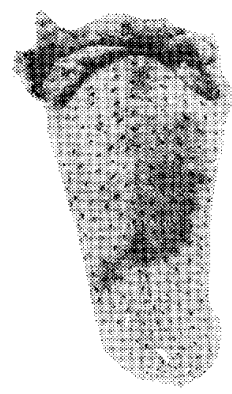

10

才

No. 80

No. 81

10

才
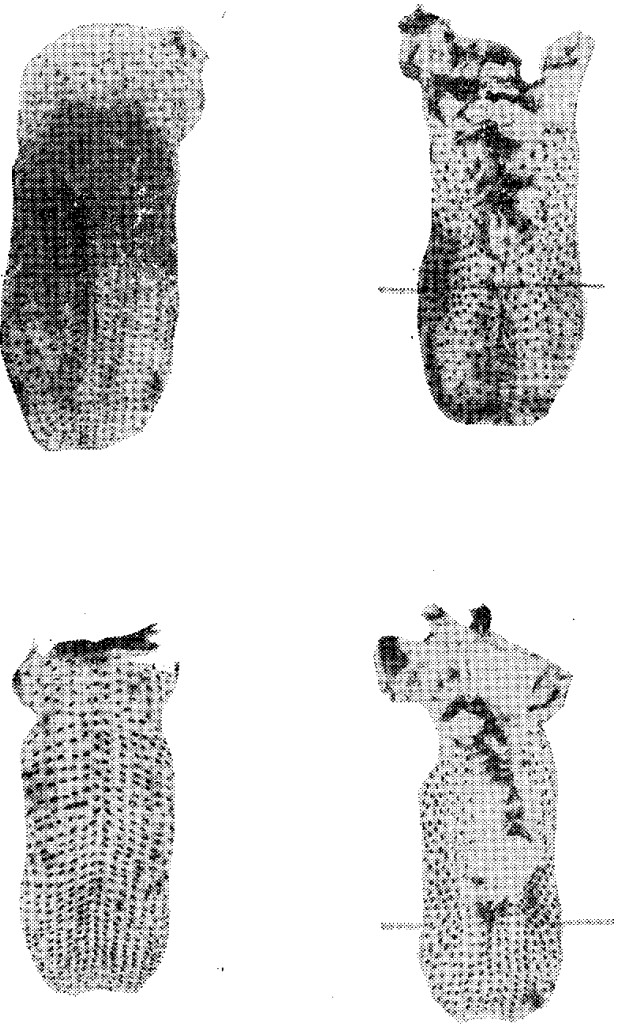

No.82

14
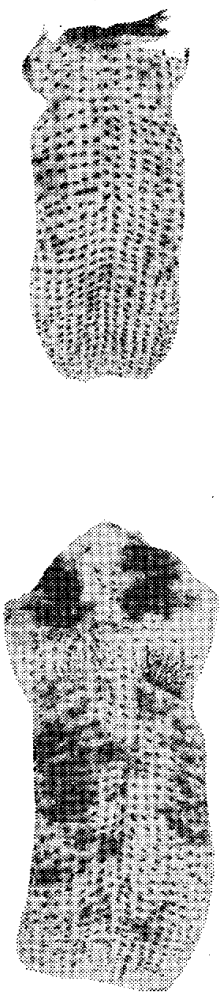

$\sqrt[3]{(3)}(2)$
舌 尖 部
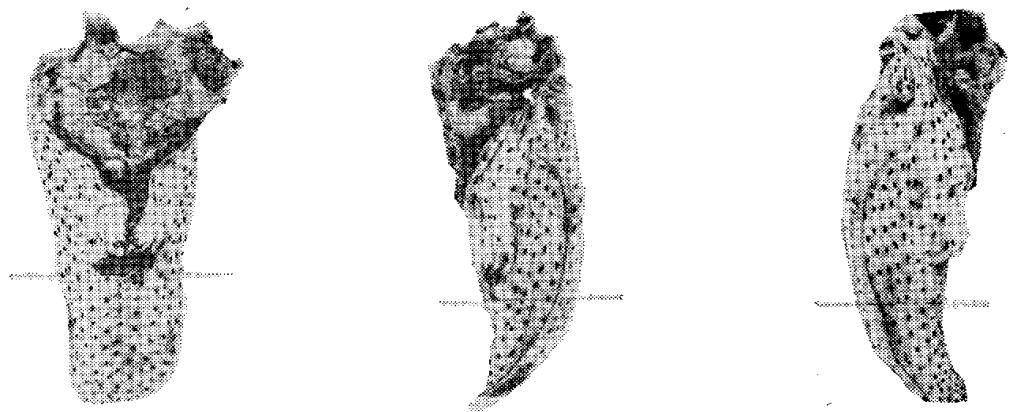

左 側 部 
II 図（1）分裂線よりみたる発育過程模式図（舌背）

発育前期

胎仔 60 日

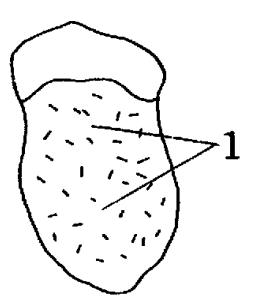

発育初期

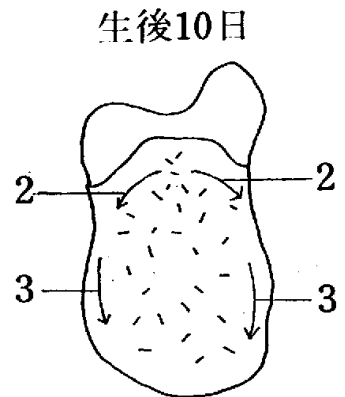

生後 2 ケ月

生後 3 ケ月～生後 6 ケ月

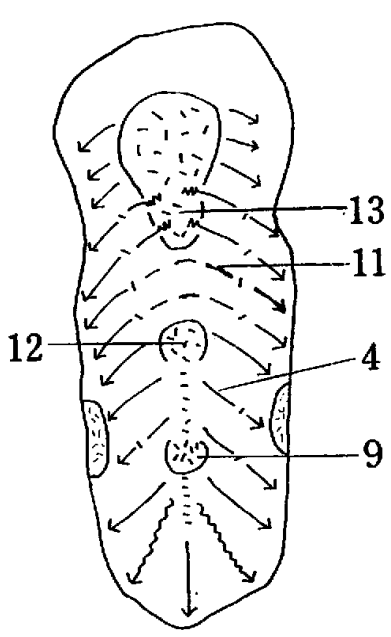

長径発育著明期

生後 20 日 生後 30 日

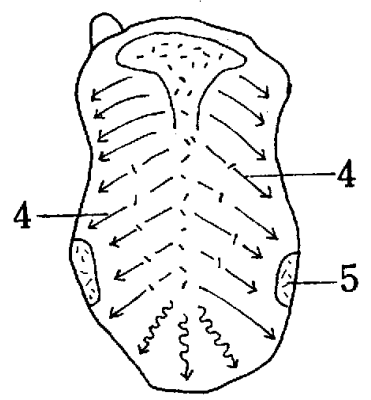

生後 7 ケ月〜生後11ケ月

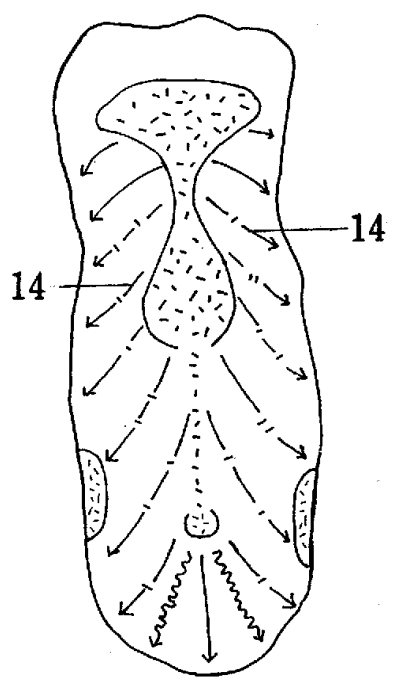

生長完了期

生後 1 年 一生後 6 年

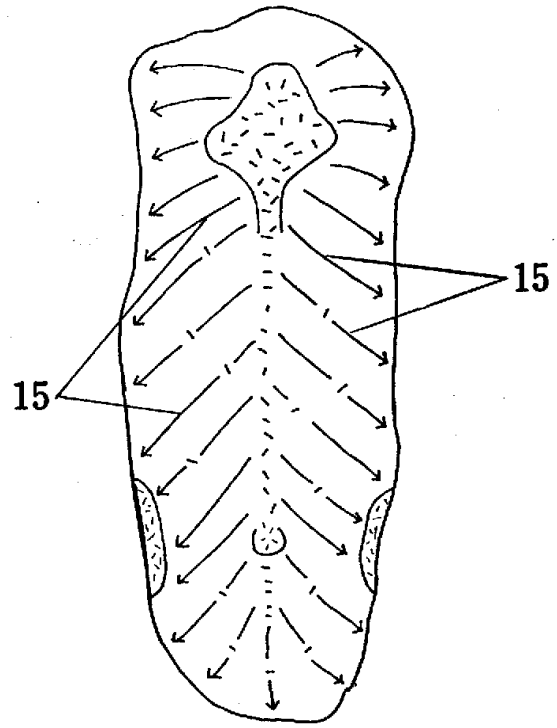

萎縮 期

生後10年～生後14年

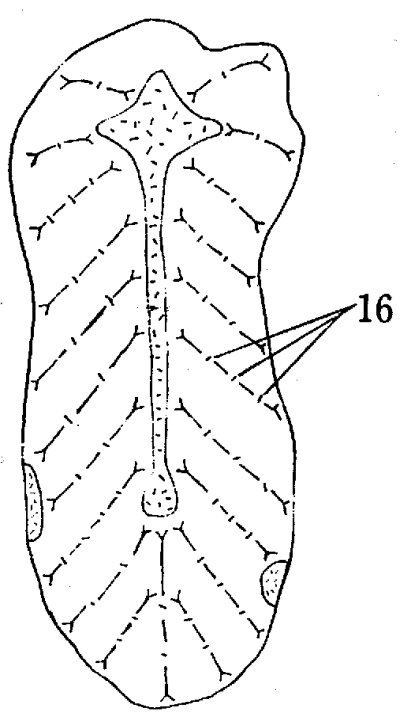


II 図（2）分裂線よりみたる発育過程模式図（舌下面）

発育前期

胎仔 60 日

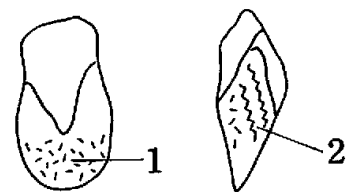

発育初期

生後 10 日

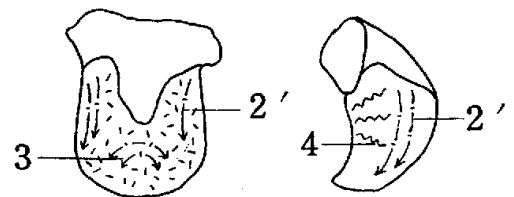

生後 30 日

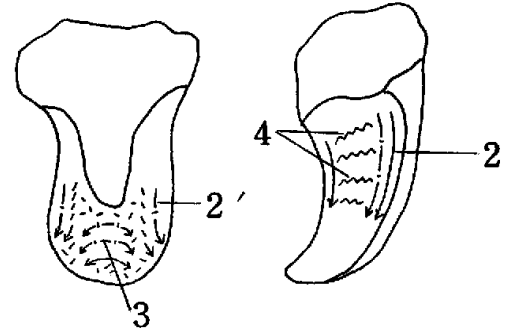

横厚径発育著明期

\section{生後 2 ケ月}
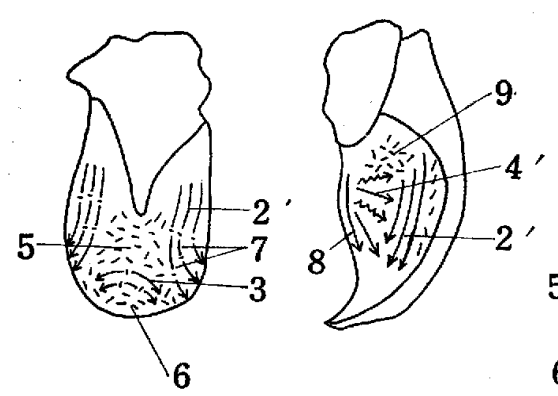

生後 3 ケ月～生後 6 ケ月
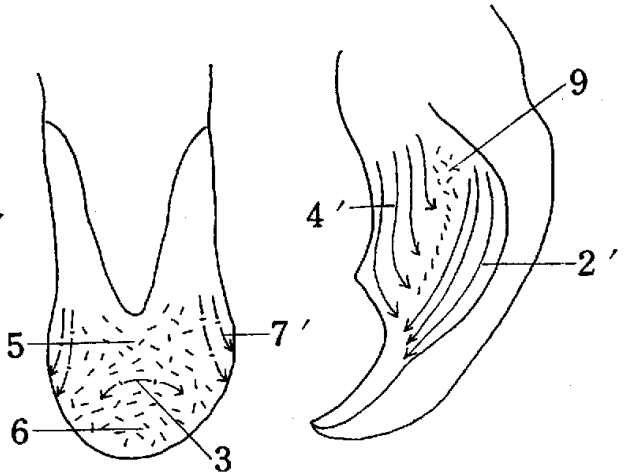

生長完了期

生後 1 年 一生後 6 年
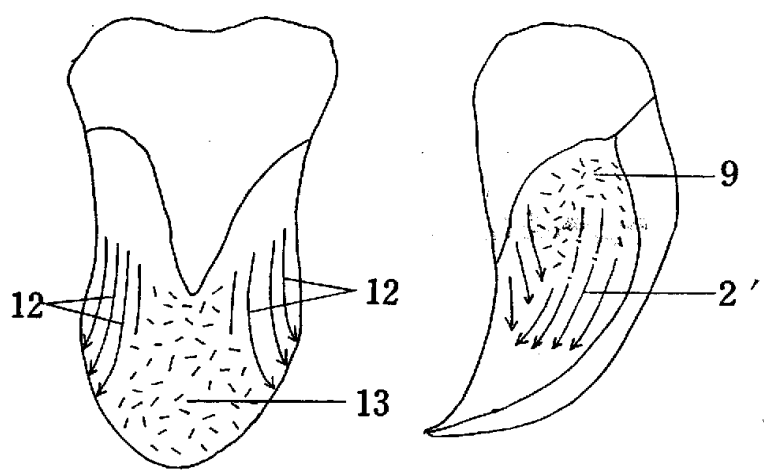

長径発育著明期

生後 7 ケ月－生後11ケ月
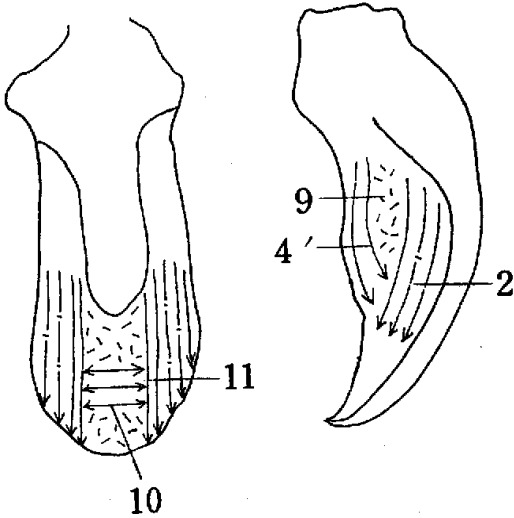

萎縮 期 生後10年一生後14年

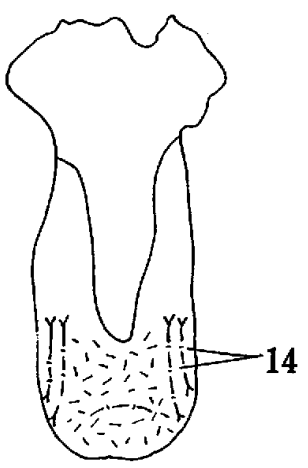

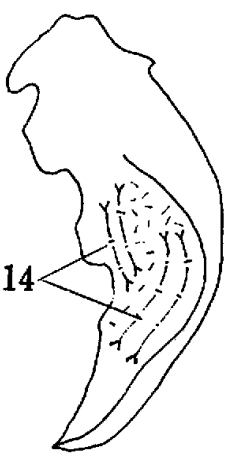




\section{III 図（外舌筋の状況と組織図の横断位置を示す）}

外側面

横断位置

内側面

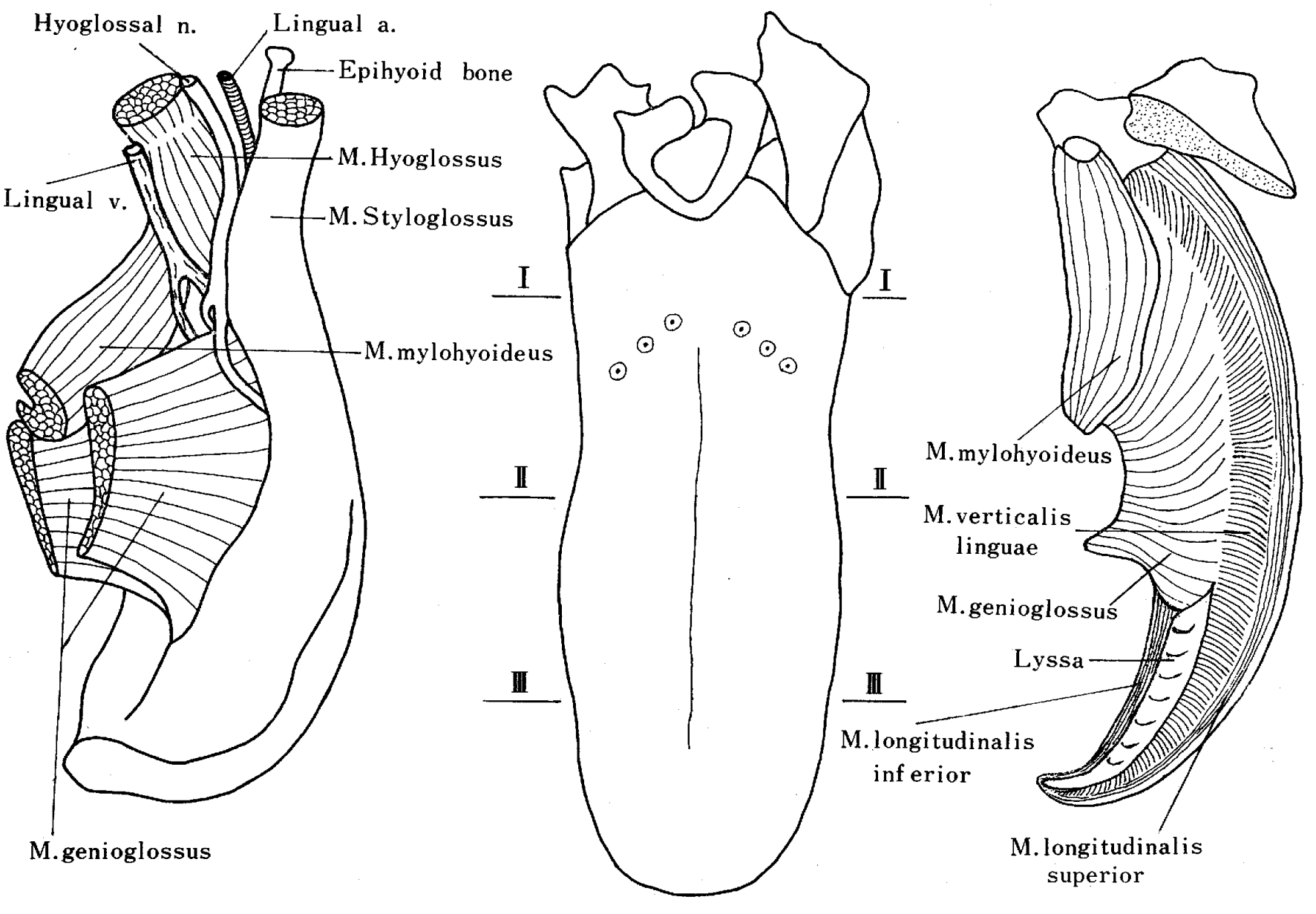


IV 図(1) 各発育期における舌筋発育状況を示す組織図

発育前期（胎仔 60 日）
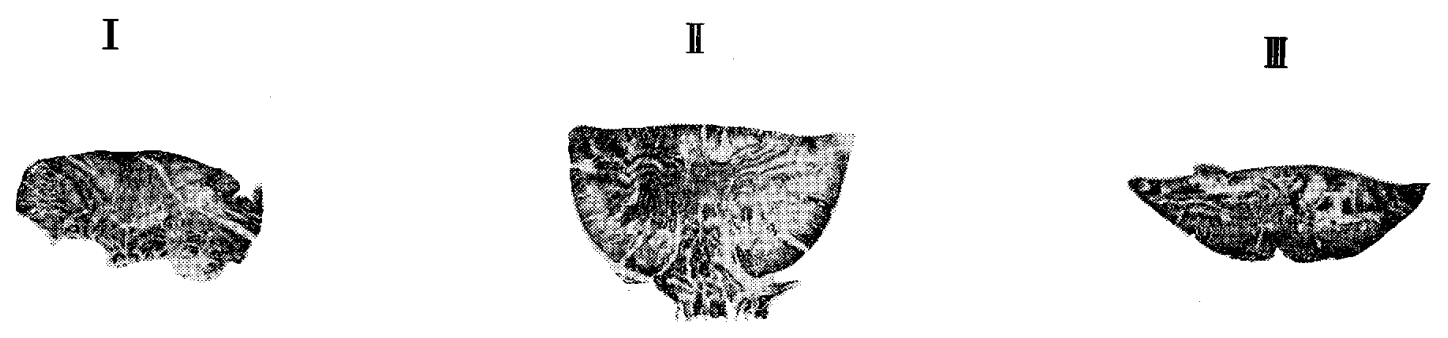

発育初期（生後10日）
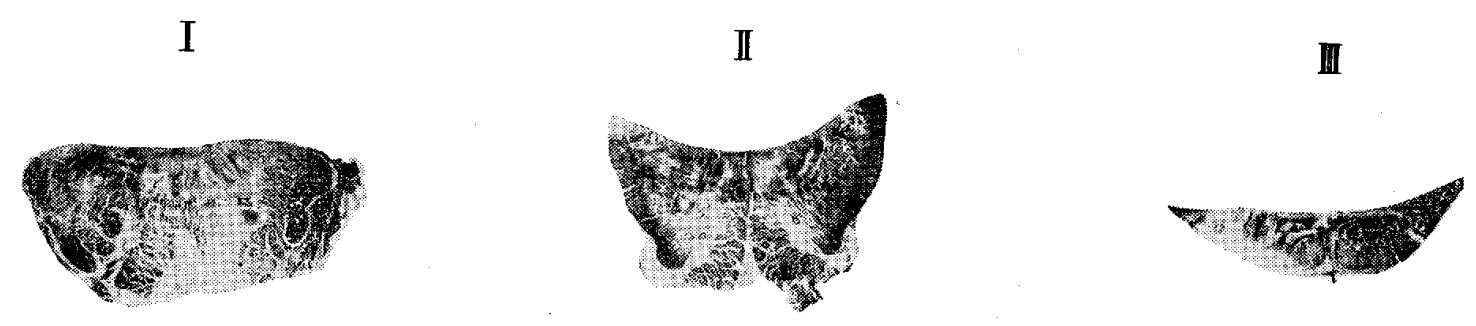

\section{(生後30日)}

I

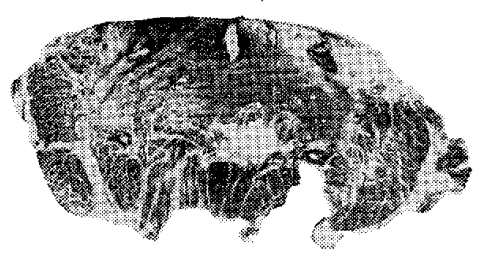

II

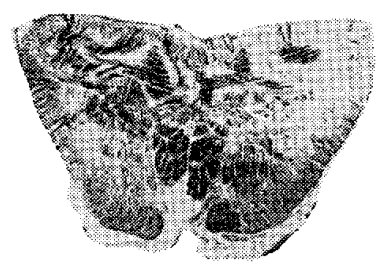

III

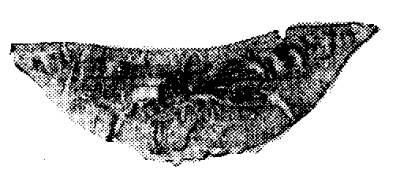

横厚径発育著明期（生後 2 ケ月）

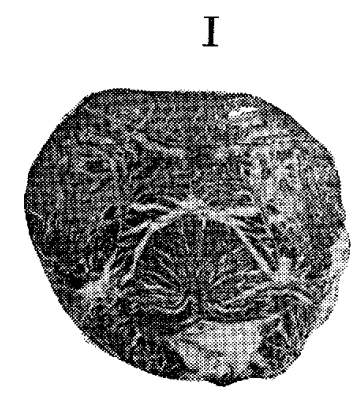

II

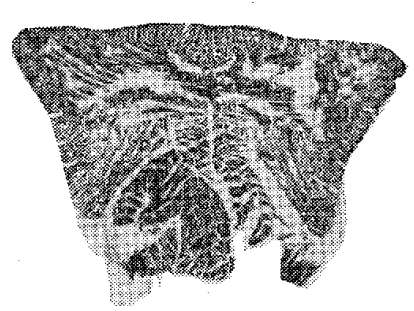

III

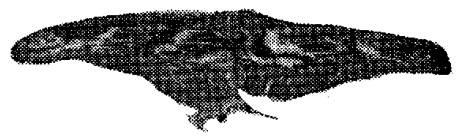


N図 (2)

\section{I}

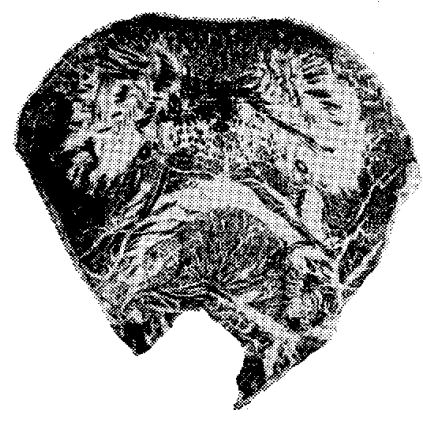

(生後6 ケ月)

\section{II}

長径発育蓄明期（生後10ケ月）

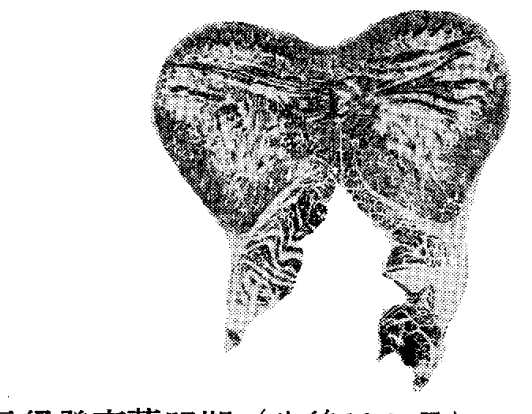

II M.transversus

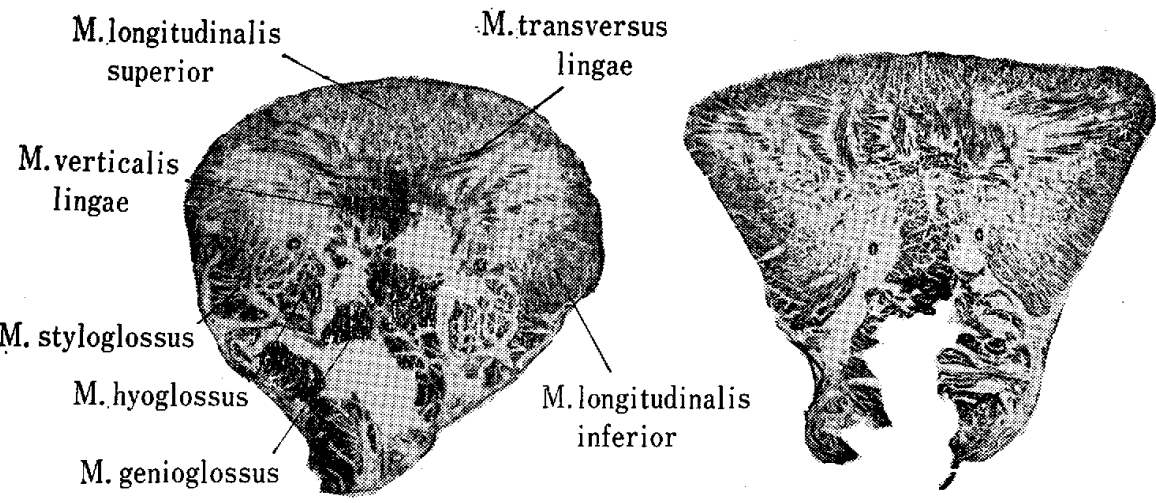

生長完了期（生後 1 年)

I

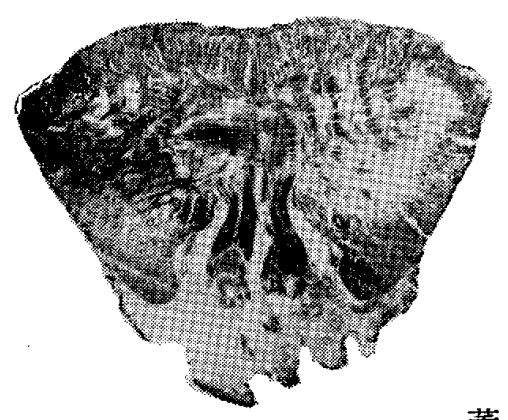

I

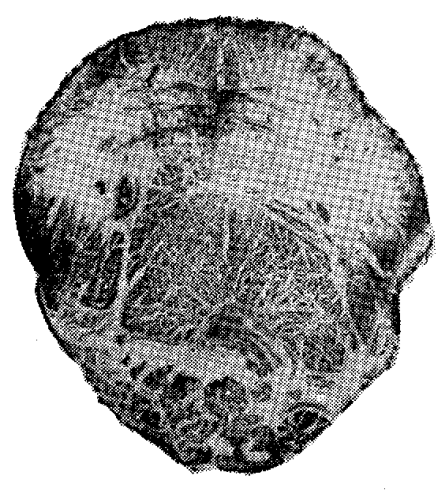

II

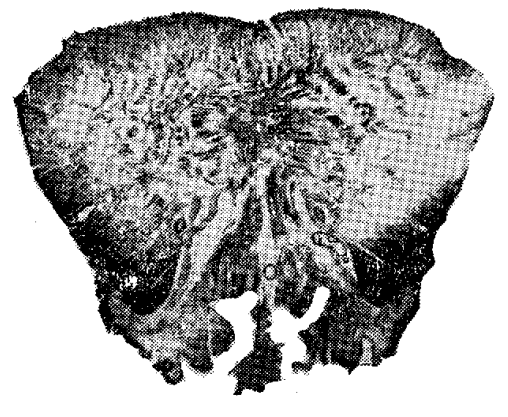

萎縮 期 (生後14年)

II

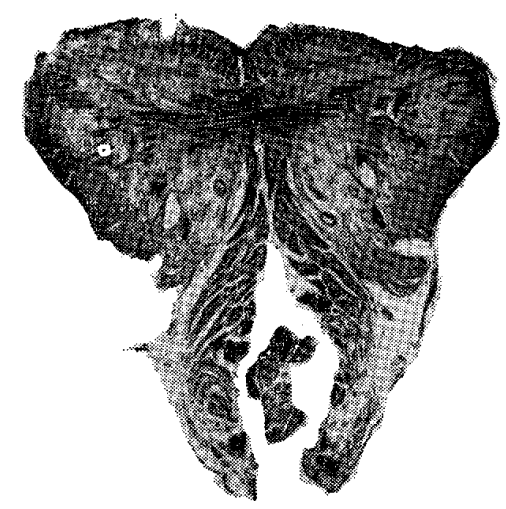

II

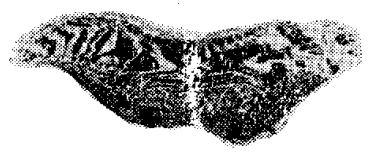

III

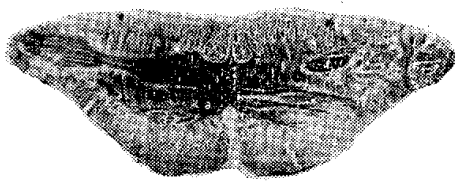

III
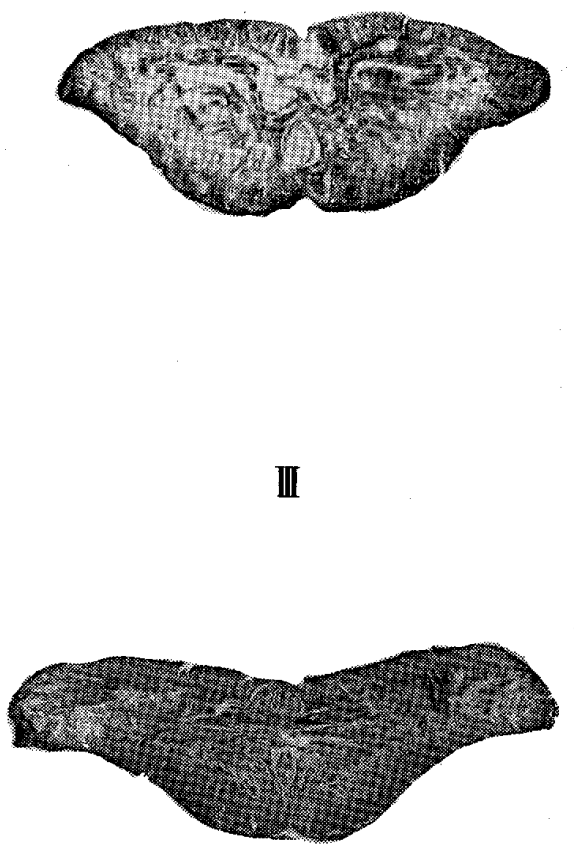
V 図

A

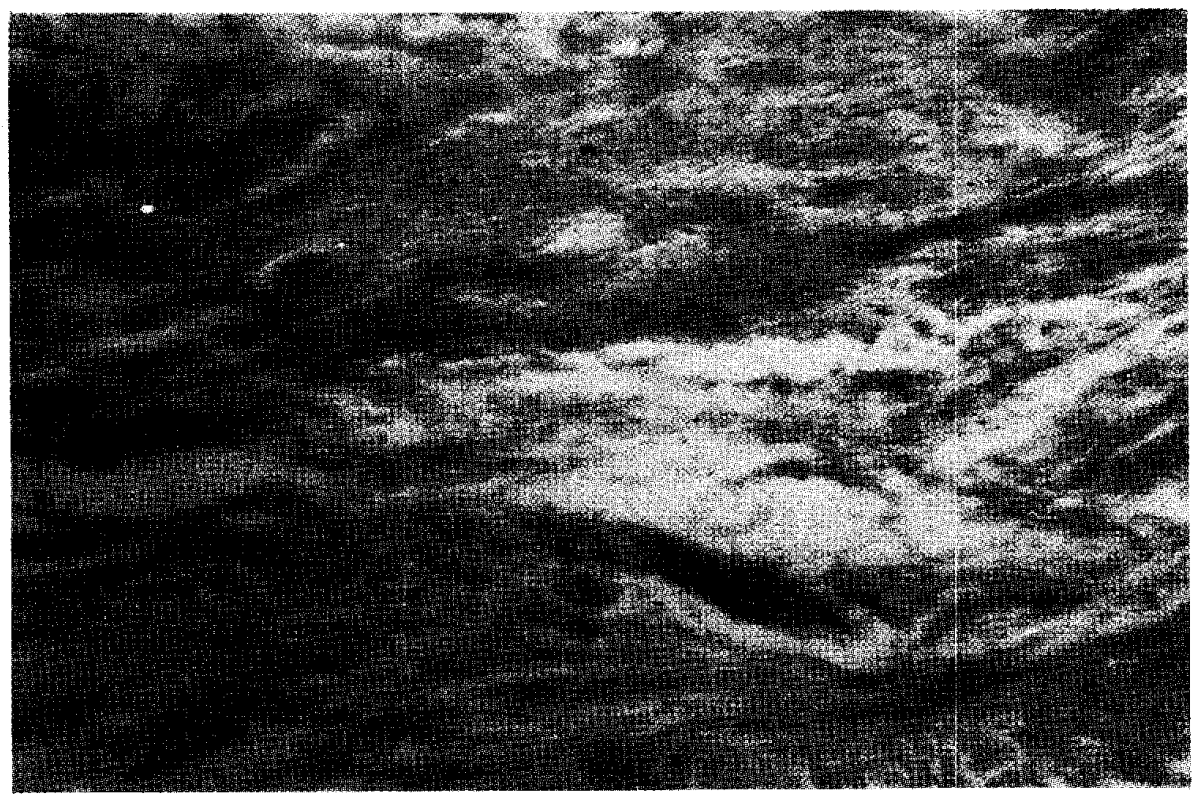

B

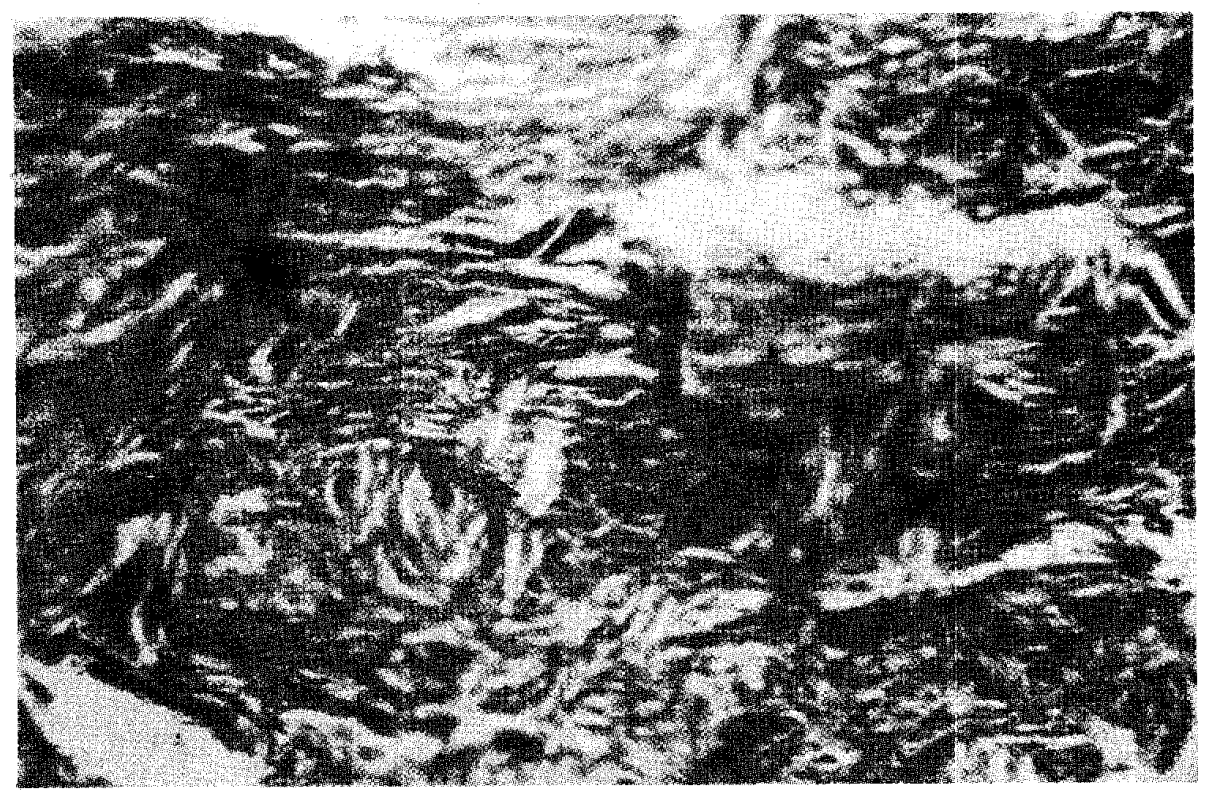

分裂線と線維走行との関係を示す組織写真
A. H. und E 染色
B. Azan 染色 